\title{
Article \\ Identification of a Quinone Derivative as a YAP/TEAD Activity Modulator from a Repurposing Library
}

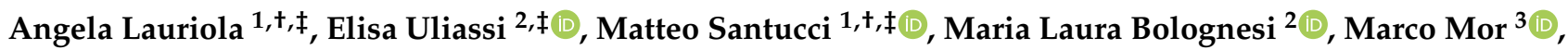

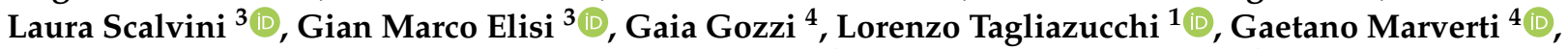 \\ Stefania Ferrari ${ }^{1}$, Lorena Losi ${ }^{1}$, Domenico $D^{\prime}$ Arca ${ }^{4, *}$ and Maria Paola Costi ${ }^{1, *}$ (i)
}

check for updates

Citation: Lauriola, A.; Uliassi, E.; Santucci, M.; Bolognesi, M.L.; Mor, M.; Scalvini, L.; Elisi, G.M.; Gozzi, G.; Tagliazucchi, L.; Marverti, G.; et al. Identification of a Quinone Derivative as a YAP/TEAD Activity Modulator from a Repurposing Library. Pharmaceutics 2022, 14, 391. https://doi.org/10.3390/ pharmaceutics14020391

Academic Editors: Juan F. Santibanez César A. Echeverría and Victor Hugo Villar

Received: 30 November 2021

Accepted: 28 January 2022

Published: 10 February 2022

Publisher's Note: MDPI stays neutral with regard to jurisdictional claims in published maps and institutional affiliations.

Copyright: (c) 2022 by the authors. Licensee MDPI, Basel, Switzerland. This article is an open access article distributed under the terms and conditions of the Creative Commons Attribution (CC BY) license (https:// creativecommons.org/licenses/by/ $4.0 /)$.
1 Department of Life Sciences, University of Modena and Reggio Emilia, Via G. Campi 103, 41125 Modena, Italy; angela.lauriola@univr.it (A.L.); matteo.santucci@univr.it (M.S.); lorenzo.tagliazucchi@unimore.it (L.T.); sferrari591@gmail.com (S.F.); lorena.losi@unimore.it (L.L.)

2 Department of Pharmacy and Biotechnology, Alma Mater Studiorum-University of Bologna, Via Belmeloro 6, 40126 Bologna, Italy; elisa.uliassi3@unibo.it (E.U.); marialaura.bolognesi@unibo.it (M.L.B.)

3 Dipartimento di Scienze degli Alimenti e del Farmaco, Università degli Studi di Parma, Parco Area delle Scienze 27/A, I, 43124 Parma, Italy; marco.mor@unipr.it (M.M.); laura.scalvini@unipr.it (L.S.); gianmarco.elisi@unipr.it (G.M.E.)

4 Department of Biomedical, Metabolic and Neural Sciences, University of Modena and Reggio Emilia, Via G. Campi 287, 41125 Modena, Italy; g.gozzi@holostem.com (G.G.); gaetano.marverti@unimore.it (G.M.)

* Correspondence: domenico.darca@unimore.it (D.D.); mariapaola.costi@unimore.it (M.P.C.)

+ Department of Biotechnology, University of Verona, Strada Le Grazie 15, 37134 Verona, Italy.

$\ddagger$ These authors contributed equally to this work.

\begin{abstract}
The transcriptional regulators YAP (Yes-associated protein) and TAZ (transcriptional coactivator with PDZ-binding motif) are the major downstream effectors in the Hippo pathway and are involved in cancer progression through modulation of the activity of TEAD (transcriptional enhanced associate domain) transcription factors. To exploit the advantages of drug repurposing in the search of new drugs, we developed a similar approach for the identification of new hits interfering with TEAD target gene expression. In our study, a 27-member in-house library was assembled, characterized, and screened for its cancer cell growth inhibition effect. In a secondary luciferase-based assay, only seven compounds confirmed their specific involvement in TEAD activity. IA5 bearing a p-quinoid structure reduced the cytoplasmic level of phosphorylated YAP and the YAP-TEAD complex transcriptional activity and reduced cancer cell growth. IA5 is a promising hit compound for TEAD activity modulator development.
\end{abstract}

Keywords: TEAD transcription factor; leads repurposing; luciferase assay; chemoinformatic; p-quinoid derivatives

\section{Introduction}

Yes1-associated protein (YAP) and transcriptional co-activator with PDZ-binding motif (TAZ) are two oncogenic transcriptional co-activators that bind the transcriptional enhanced associate domain (TEAD) transcription factors and are, thus, involved in cell proliferation. In fact, the YAP and TAZ functional activity is implicated in the tumorigenesis of various cancers, including breast [1,2], colon [3], and lung [4]. Indeed, in tumors, these proteins can reprogram cancer cells into cancer stem cells and incite tumor initiation, progression, and metastasis [5-7]. They are strictly regulated by the Hippo kinase cascade, whose output effect consists in inhibiting their nuclear translocation and responsive target gene transcription [6,8]. As shown in Figure 1, the kinasic core-module of the Hippo pathway, including MST1/2 (STK4, Serine/Threonine Kinase 4), Mob1A/1B (MOB kinase activator 1(A/B), and SAV1 (Salvador Family WW Domain Containing Protein 1), induces LATS1/2 (Large tumor suppressor kinase 1)-mediated phosphorylation of YAP with its consequent cytoplasmic retention (Ser127) or destruction by proteasomal degradation (Ser381) [9]. 
In addition, several cell junction proteins are able to bind YAP by direct protein-protein interactions (PPIs), preventing its translocation to the nucleus, and then regulating the YAP subcellular localization in a phosphorylation-independent manner [10]. AMOT family proteins and $\alpha$-catenin are two important components of tight- (TJs) and adherent-junctions (AJs), respectively. An interaction between AMOT and YAP/TAZ has been identified, and it is not dependent on the YAP/TAZ phosphorylation status, consequently resulting in reduced YAP/TAZ nuclear localization and activity. Unlike AMOT, YAP/ $\alpha$-catenin binding is based on the YAP-phosphorylation at Ser127; in this way, the 14-3-3 complex can interact with phosphorylated YAP (pYAP) and then with $\alpha$-catenin protein, to sequester YAP at AJs and prevent its dephosphorylation/activation. Unlike the phosphorylation on Ser127, YAP phosphorylated on Ser381 undergoes a proteasomal degradation through the recruitment of SCF $\beta$-TRCP ubiquitin E3 ligase complex, with a consequent decrease of YAP protein levels. Based on the previous considerations, inhibiting YAP/TAZ-TEAD complex represents an attractive and viable strategy to restrain the transcriptional outputs of YAP/TAZ for novel cancer therapies [11-13].

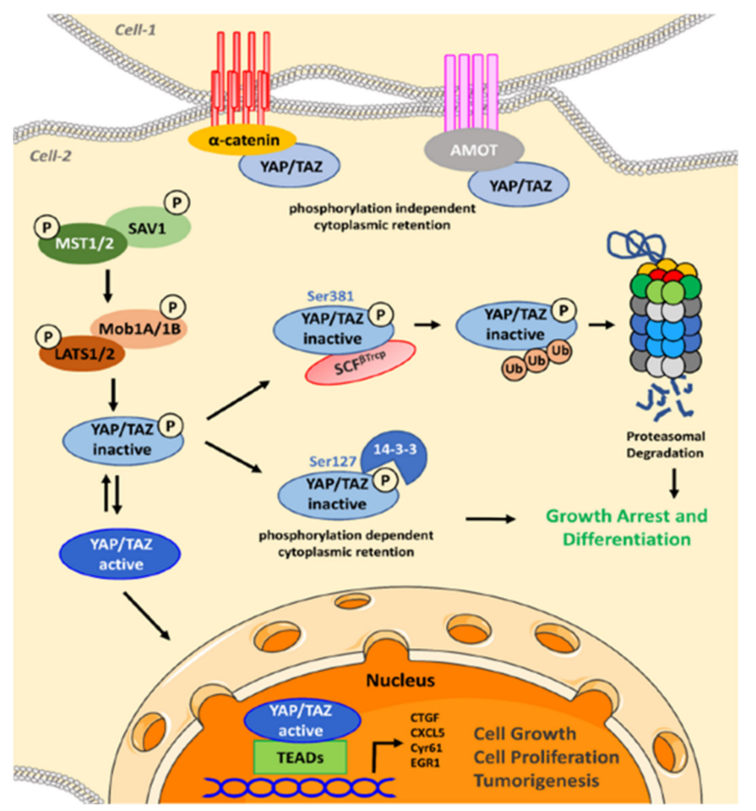

Figure 1. Regulation of YAP/TAZ activity. The YAP/TAZ transcription co-activator is the main downstream effector of Hippo kinase cascade signaling. LATS1/2-mediated YAP-phosphorylation (YAP inactive, negative feedback) induces its cytoplasmic retention or degradation via proteasome, while YAP, not phosphorylated (YAP active), is able to translocate into the nucleus and to activate the transcription of oncogenic YAP-responsive target genes by the interaction with TEAD transcription factors.

Current inhibitors of YAP-TEAD transcriptional activity may act by directly altering the YAP-TEAD interaction or by indirectly interfering with the complex transcriptional activity through modulation of the multiple activators [13]. This can happen following different mechanisms, summarized in a sunburst graph and detailed description in Supplementary Materials (Figure S1 and pages 1,2). All these compounds have the same common output, to directly or indirectly block YAP-TEAD activity [14]. Among the direct inhibitors, verteporfin (VP), an FDA-approved photosensitizing compound, has been reported as a TEAD gene transcription disrupter [15-17]. However, its mechanism of action is not yet fully clarified. Similar to VP, the pentacyclic terpenoid, celastrol, blocked YAP-TEAD binding, leading to the inhibition of TEAD-dependent target gene expression in cancer cell lines [18]. Additionally, peptides derived from both the YAP $\Omega$-loop sequence (YAP cyclic peptide 17 and TB1G1 cystine-dense peptide) $[19,20]$ and the co-regulator Vgll4, [21] a structurally YAP/TAZ mutually-exclusive competitor for TEAD binding, were shown 
to act as protein-protein interaction (PPI) disruptors. Small molecules have been also designed to target the TEAD surface interacting with the YAP $\Omega$-loop [22]. Digitoxin was putatively identified as a YAP WW domain modulator by in silico analysis [23] and was found to promote YAP protein levels in the cytoplasm [24]. The palmitate-binding pocket (PBP) represents the most druggable pocket located at the center of the TEAD's YAP/TAZ binding domain, and several small molecules have been proposed (flufenamic acid derivatives, DC-TEADin02 [25] and K-975 [26]). On the other hand, indirect inhibitors include structurally different compounds, targeting a great variety of proteins (e.g., epigenetic proteins, GPCRs, kinases), but with all ultimately acting as LATS protein phosphorylation enhancers (Figure S1, Supplementary Materials). Phosphatases and intracellular kinases inhibitors (calyculin-A, dasatinib, and trametinib), as well as the inhibitors of cell surface receptors (glucagon/epinephrin/losartan and erlotinib/pazopanib/axitinib); the mevalonate pathway inhibitors (statins, zoledronic acid and GGTI-298); and the cytoskeletal actin-, epigenetic-, and cellular energy stress-modulators (blebbistatin/latrunculin-A/XAV-939, panobinostat/I-BET151 and metformin/AICAR) have been reported as strong modulators of the YAP-TEAD network by enhancing the LATS-dependent inhibitory phosphorylation of YAP/TAZ, to reduce their transcriptional outputs. Many of these drugs have the potential to be repurposed as YAP/TAZ indirect inhibitors, to treat various solid cancers [13].

With the aim of identifying and characterizing new compounds with lead-like properties that could modulate YAP-TEAD activity, in the present study, we followed a repurposing strategy, by selecting and screening a small library of 27 compounds. This library contains preclinical compounds contributed by our academic laboratories in different medicinal chemistry programs. Thus, most of the collection is comprised of lead-like molecules, which offer excellent opportunities for repurposing. A few commercially available compounds, including known modulators of the Hippo pathway, were acquired as an internal reference. Since the biological crosstalk with the YAP/TAZ-TEAD pathway is mediated by PPI [27] (Figure 1), the selected compounds have structural features for acting as PPI inhibitors (iPPI) and indirectly disrupt the YAP/TAZ-TEAD interaction (Figure 2).

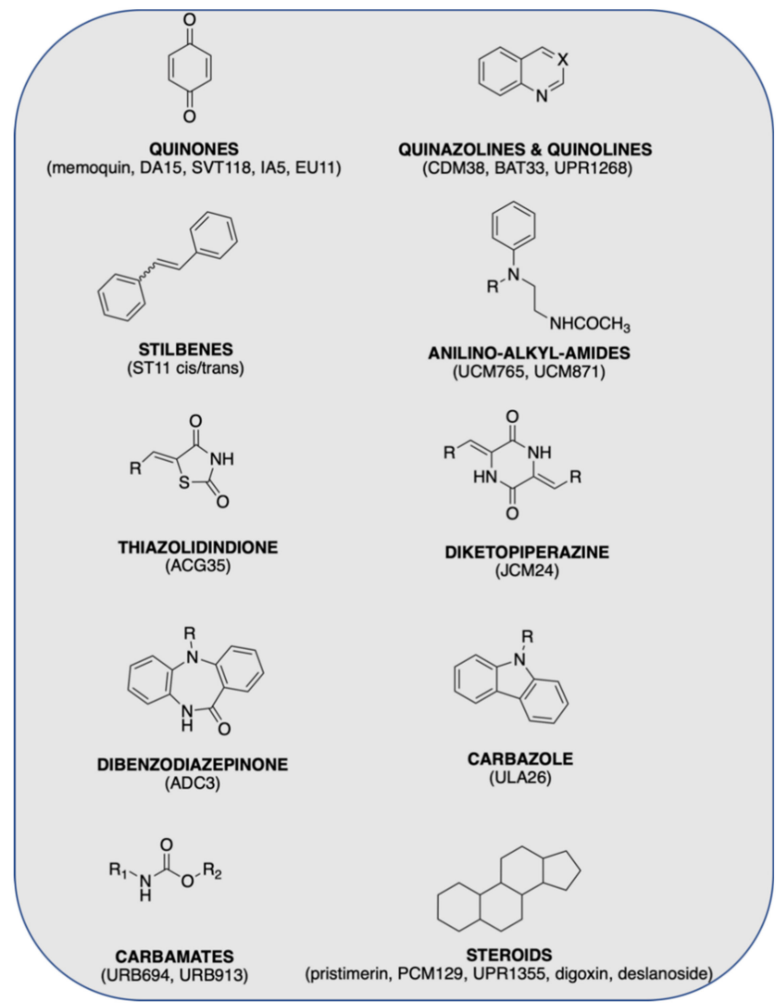

Figure 2. Scaffolds featuring the in-house repurposing library. 
The library was constructed using chemioinformatic and bioinformatic tools, to characterize investigational candidates and drugs repurposed in comparison with known inhibitors. All compounds were tested and prioritized based on their inhibitory potency in a HaCaT cell proliferation assay, used as a cellular tool to identify those compounds able to affect cell growth [24]. The best cell growth inhibitors were progressively characterized in a secondary assay for their capacity to inhibit YAP-TEAD activity in a HaCaT cell luciferase assay and to display cytotoxic effects on several cancer cell lines. We finally ascertained that some selected compounds specifically interfere with the YAP phosphorylation and TEAD gene expression activity in two colorectal cancer cell lines, HCT116 and HT29.

\section{Materials and Methods}

\subsection{Chemistry}

All commercially available reagents (including pristimerin, digoxin, deslanoside, and verteporfin) and solvents were purchased from Sigma-Aldrich, Fluka (Italy), TCI, Alpha Aesar, without further purification. Reactions were followed by analytical thin layer chromatography (TLC), performed on precoated TLC plates $(0.20 \mathrm{~mm}$ silica gel 60 with UV254 fluorescent indicator, Merck). Developed plates were air-dried and visualized by exposure to UV light $(1=254 \mathrm{~nm}$ and $365 \mathrm{~nm})$. Reactions involving the generation or consumption of amine were visualized using bromocresol green spray $(0.04 \%$ in $\mathrm{EtOH}$, made blue by $\mathrm{NaOH})$. Column chromatography purifications were performed under flash conditions using Kieselgel 40 (0.040-0.063 mm; Merck). NMR experiments for compound 1 were run on a Varian VXR400, while for compound 2-4 on a Varian VXR300 instrument. ${ }^{1} \mathrm{H}$ and ${ }^{13} \mathrm{C}$ NMR spectra were acquired at $300 \mathrm{~K}$ using deuterated chloroform $\left(\mathrm{CDCl}_{3}\right)$ as solvent. Chemical shifts (d) are reported in parts per million (ppm) relative to the residual solvent peak as an internal reference and coupling constants $(J)$ are reported in hertz $(\mathrm{Hz})$. Spin multiplicity is reported as: $\mathrm{s}=$ singlet, $\mathrm{br} \mathrm{s}=$ broad singlet, $\mathrm{d}=$ doublet, $\mathrm{t}=$ triplet, $\mathrm{q}=$ quartet, $\mathrm{m}=$ multiplet. Compounds were named following IUPAC rules, as applied by ChemBioDraw Ultra (version 14.0). Mass spectra and purity determinations were recorded on a Waters ZQ 4000, Waters XevoG2-XSQTof, acuity arc-QDA LC-MS apparatus with electrospray ionization (ESI) in positive mode. UPLC-MS analyses were run on a Waters ACQUITY UPLC/MS system, consisting of a QDa mass spectrometer equipped with an electrospray ionization interface and a $2489 \mathrm{UV} / \mathrm{Vis}$ detector $(254 \mathrm{~nm}$ and $365 \mathrm{~nm})$. The analyses were performed on an XBridge BEH C18 column $(100 \times 2.1 \mathrm{~mm}$ i.d., particle size $2.5 \mu \mathrm{m})$ with a XBridge BEH C18 VanGuard Cartridge precolumn $(5 \mathrm{~mm} \times 2.1 \mathrm{~mm}$ i.d., particle size $1.8 \mu \mathrm{m})$. The mobile phase was composed of $\mathrm{H}_{2} \mathrm{O}(0.1 \%$ formic acid) (A) and $\mathrm{MeCN}(0.1 \%$ formic acid) (B), using the following gradient: $0-0.78 \mathrm{~min}, 20 \% \mathrm{~B}$; 0.78-2.87 $\mathrm{min}, 20-95 \% \mathrm{~B} ; 2.87-3.54 \mathrm{~min}, 95 \% \mathrm{~B} ; 3.54-3.65 \mathrm{~min}, 95-20 \% \mathrm{~B} ; 3.65-5.73,20 \% \mathrm{~B}$. Flow rate: $0.8 \mathrm{~mL} / \mathrm{min}$. 1 showed a purity of $\geq 98 \%$.

\subsection{Synthesis of N-(2-(Benzyloxy)benzyl)ethanamine (2)}

A solution of 2-(benzyloxy)benzaldehyde $(0.5 \mathrm{~g}, 2.36 \mathrm{mmol})$ and ethylamine $(0.127 \mathrm{~g}$, $2.83 \mathrm{mmol})$ in toluene $(10 \mathrm{~mL})$ containing $\mathrm{MgSO}_{4}$ was stirred at room temperature for $1 \mathrm{~h}$, then, the solvent was evaporated under vacuum. The resulting residue was rinsed with $\mathrm{MeOH}(35 \mathrm{~mL})$, and $\mathrm{NaBH}_{4}(0.11 \mathrm{~g}, 2.83 \mathrm{mmol})$ was added and stirring continued for a further $48 \mathrm{~h}$. After removing the solvent, the mixture was made cautiously acidic with $2 \mathrm{~N} \mathrm{HCl}$ and extracted with diethyl ether $(3 \times 15 \mathrm{~mL})$. The aqueous phase was made basic with $\mathrm{Na}_{2} \mathrm{CO}_{3}$ and extracted with $\mathrm{CH}_{2} \mathrm{Cl}_{2}(3 \times 25 \mathrm{~mL})$. The organic phase was separated, dried, and evaporated to give $0.41 \mathrm{~g}$ (72\% yield) of the title compound as a transparent oil. ${ }^{1} \mathrm{H}-\mathrm{NMR}\left(\mathrm{CDCl}_{3}, 300 \mathrm{MHz}\right) \delta 1.19(\mathrm{t}, J=6.6 \mathrm{~Hz}, 3 \mathrm{H}), 2.78(\mathrm{q}, J=6.3 \mathrm{~Hz}, 2 \mathrm{H}), 4.00(\mathrm{~s}, 2 \mathrm{H})$, $5.17(\mathrm{~s}, 2 \mathrm{H}), 6.97-7.02(\mathrm{~m}, 2 \mathrm{H}), 7.28-7.50$ (m complex, $7 \mathrm{H})$.

\subsection{Synthesis of 2-(6-((2-(Benzyloxy)benzyl)(ethyl)amino)hexyl)isoindoline-1,3-dione (3)}

To a solution of $2(0.41 \mathrm{~g}, 1.70 \mathrm{mmol})$ in DMF $(15 \mathrm{~mL}), N$-(6-bromohexyl)phthalimide $(0.264 \mathrm{~g}, 0.85 \mathrm{mmol})$ and $\mathrm{KI}(0.7 \mathrm{~g}, 5.11 \mathrm{mmol})$ were consecutively added, and the reaction 
mixture was stirred for $12 \mathrm{~h}$ at $90^{\circ} \mathrm{C}$. After cooling to room temperature, the mixture was acidified with aqueous $\mathrm{KHSO}_{4}$ and extracted with $\mathrm{CH}_{2} \mathrm{Cl}_{2}(3 \times 25 \mathrm{~mL})$. The organic phase was separated, dried, and evaporated to give a crude material, which was purified by flash chromatography. Eluting with $\mathrm{CH}_{2} \mathrm{Cl}_{2}$ /petroleum ether/ $\mathrm{MeOH} /$ aqueous $33 \%$ ammonia (4.5:5.0:0.5:0.05) afforded $0.2 \mathrm{~g}\left(50 \%\right.$ yield) of the title compound as a yellow oil. ${ }^{1} \mathrm{H}-\mathrm{NMR}$ $\left(\mathrm{CDCl}_{3}, 300 \mathrm{MHz}\right) \delta 1.06(\mathrm{t}, J=6.9 \mathrm{~Hz}, 3 \mathrm{H}), 1.33(\mathrm{~s}, 2 \mathrm{H}), 1.51(\mathrm{~s}, 2 \mathrm{H}), 1.67(\mathrm{t}, J=6.6 \mathrm{~Hz}, 2 \mathrm{H})$, $2.49(\mathrm{t}, J=6.7 \mathrm{~Hz}, 2 \mathrm{H}) 2.54-2.61(\mathrm{~m}, 2 \mathrm{H}) 3.69(\mathrm{t}, J=6.3 \mathrm{~Hz}, 4 \mathrm{H}), 3.96(\mathrm{~s}, 2 \mathrm{H}), 5.11(\mathrm{~s}, 2 \mathrm{H})$, 6.97-7.05 (m, 3H), 7.34-7.49 (m complex, 6H), 7.70-7.73 (m, 2H), 7.84-7.87 (m, 2H).

\subsection{Synthesis of $N^{1}-(2-(B e n z y l o x y) b e n z y l)-N^{1}$-ethylhexane-1,6-diamine (4)}

A solution of $3(0.2 \mathrm{~g}, 0.4 \mathrm{mmol})$ and $\mathrm{NH}_{2} \mathrm{NH}_{2} \bullet \mathrm{H}_{2} \mathrm{O}(0.12 \mathrm{~mL}, 2.4 \mathrm{mmol})$ in EtOH $(5 \mathrm{~mL})$ was refluxed for $1 \mathrm{~h}$. After cooling to room temperature, the resulting suspension was filtered, and the filtrate was evaporated under vacuum. The obtained crude mixture was dissolved in $\mathrm{H}_{2} \mathrm{O}$ acidified with $\mathrm{KHSO}_{4}$ and extracted with $\mathrm{Et}_{2} \mathrm{O}(3 \times 20 \mathrm{~mL})$. Then, the aqueous phase was made basic with $\mathrm{NaHCO}_{3}$ and extracted with $\mathrm{CH}_{2} \mathrm{Cl}_{2}(3 \times 20 \mathrm{~mL})$. The organic phase was separated, dried, and evaporated to give $0.12 \mathrm{~g}$ ( $88 \%$ yield) of the title compound as a yellow oil. ${ }^{1} \mathrm{H}-\mathrm{NMR}\left(\mathrm{CDCl}_{3}, 300 \mathrm{MHz}\right) \delta 1.06(\mathrm{t}, J=6.8 \mathrm{~Hz}, 3 \mathrm{H}), 1.30-1.47$ (m, $8 \mathrm{H}), 2.45-2.71(\mathrm{~m} .6 \mathrm{H}), 3.69(\mathrm{~s}, 2 \mathrm{H}), 5.11$ (s, 2H) 6.92-7.51 (m complex, 9H).

\subsection{Synthesis of 2-((6-((2-(Benzyloxy)benzyl)(ethyl)amino hexyl)amino)-5-((6-(ethyl(2-} (phenoxymethyl) benzyl)amino)hexyl)amino)cyclohexa-2,5-diene-1,4-dione (1)

A solution of $4(0.12 \mathrm{~g}, 0.35 \mathrm{mmol})$ and 2,5-dimethoxy-1,4-benzoquinone $(0.029 \mathrm{~g}$, $0.17 \mathrm{mmol})$ in $\mathrm{EtOH}(6 \mathrm{~mL})$ was stirred for $3 \mathrm{~h}$ at $60^{\circ} \mathrm{C}$. After cooling to room temperature, stirring was continued for a further $2 \mathrm{~h}$. Then, the solvent was evaporated, and the resulting precipitate was washed with $\mathrm{Et}_{2} \mathrm{O}$ to give $0.12 \mathrm{~g}$ (85\% yield) of the title compound as a red solid. ${ }^{1} \mathrm{H}-\mathrm{NMR}\left(\mathrm{CDCl}_{3}, 400 \mathrm{MHz}\right) \delta 1.04(\mathrm{t}, J=7.1 \mathrm{~Hz}, 6 \mathrm{H}), 1.18-1.36(\mathrm{~m}, 8 \mathrm{H}), 1.36-1.52$ $(\mathrm{m}, 4 \mathrm{H}), 1.53-1.68(\mathrm{~m}, 4 \mathrm{H}), 2.45(\mathrm{t}, J=6.9 \mathrm{~Hz}, 4 \mathrm{H}), 2.55(\mathrm{q}, J=7.0 \mathrm{~Hz}, 4 \mathrm{H}), 3.09(\mathrm{q}, J=13.4$, $6.8 \mathrm{~Hz}, 4 \mathrm{H}), 3.66(\mathrm{~s}, 4 \mathrm{H}), 5.09(\mathrm{~s}, 4 \mathrm{H}), 5.29(\mathrm{~s}, 2 \mathrm{H}), 6.57(\mathrm{t}, J=6.6 \mathrm{~Hz}, 2 \mathrm{H}), 6.86-7.01(\mathrm{~m}$, $4 \mathrm{H}), 7.19(\mathrm{td}, J=7.7,1.4 \mathrm{~Hz}, 2 \mathrm{H}), 7.29-7.35(\mathrm{~m}, J=7.2 \mathrm{~Hz}, 2 \mathrm{H}), 7.35-7.42(\mathrm{~m}, 4 \mathrm{H}), 7.45(\mathrm{~d}$, $J=7.1 \mathrm{~Hz}, 4 \mathrm{H}) ;{ }^{13} \mathrm{C}-\mathrm{NMR}\left(\mathrm{CDCl}_{3}, 100 \mathrm{MHz}\right) \delta 12.05,26.98,27.17,28.34,42.67,47.85,51.64$, $53.41,70.17,92.75,111.85,120.77,127.37,127.87,128.58,130.43,137.53,151.41,156.93,178.20$; MS $\left(\mathrm{ESI}^{+}\right) m / z 785[\mathrm{M}+\mathrm{H}]^{+}$. UPLC-MS purity (UV at $254 \mathrm{~nm}$ ) $98 \%$.

\subsection{Physicochemical Descriptors}

The physicochemical properties were calculated using the molecular descriptor calculator tool included in the QikProp module of the Canvas 3.2 platform $[27,28]$. The following descriptors were calculated: Molecular Weight (MW), ALogP, H-bond acceptors (HBA), H-bond donors (HBD), Topological Polar Surface Area (TPSA), and Rotable Bonds (RBs). For each property, a box plot was generated (Figure S2).

\subsection{Characterization of the Chemical-Space: Principal Component Analysis (PCA)}

A PCA multivariate statistical method was followed to reduce to a $2 \mathrm{D}$-visual representation the chemical space covered by the compound collection, as a function of the six molecular descriptors using the PCA module of the Canvas 3.2 platform [29]. The two drugs, verteporfin and dasatinib, were added to the screening panel as reference compounds. First, the exact number of principal components (PCs) able to explain the total variance $(\geq 80 \%)$ of the original dataset was identified. Next, the correlation magnitude of all variables for defining each single PC was evaluated (loading value $\geq \pm 0.50$ ), and PCA scores were calculated using the $k$-means clustering method as a function of six molecular descriptors. Consequently, PC score plot was generated [30,31]. Based on the distribution of PCA score values, the chemical space coverage was evaluated, and five structural complexity-based compound clusters were identified. Before performing the PCA, the original dataset was standardized by subtracting each value of the variable's mean and dividing by its standard deviation. 


\subsection{Hierarchical Clustering Analysis}

A similarity-based clustering analysis was performed to identify putative compound groupings sharing the same chemical core structure using the hierarchical clustering tool in the Canvas 3.2 platform [29]. A single binary 2D-fingerprint was first calculated for each compound, considering an extended connectivity fingerprinting 4-ECFP4, in which the atoms and the bonds were distinguished by functional type and hybridization, respectively [30]. Next, a similarity-distance matrix was obtained based on the Tanimoto coefficient (=0.9092) [32], which was used for a bottom-up approach using the complete clustering-linkage as an agglomerative clustering method [33]. The same similarity matrix was also used as input-data for RStudio open-source software (https:/ /rstudio.com/, accessed on 20 September 2021), to visually represent, as a dendrogram, the chemical similarities between molecules. With this aim, it was necessary to use the hclust algorithm, in order to translate the Canvas clustering matrix (csv file) to tree file format [34]. Sixteen compound clusters were obtained, four of which were single-populating clusters (singlets) [35]. The chemical molecules populating each single cluster were analyzed one by one and the proper common core was defined. Finally, the tree file was used as input for the iTOL online server (http:/ / itol.embl.de/, accessed on 20 November 2021) for displaying the clustering treemap $[36,37]$.

\subsection{Cell Culture}

HaCat cells were maintained in DMEM medium (Dulbecco's modified Eagle's medium; composition: $100 \mathrm{mg} / \mathrm{L}$ Glucose, Sodium Bicarbonate and pyridoxine) supplemented with 2 mM L-Glutamine and 10\% FBS (fetal bovine serum). A2780 and A2780/CP cell lines were maintained in RPMI medium, containing 10\% FBS. HT29, HCT116, and HCA46 (colorectal cancer cell lines) were maintained in DMEM medium. Cells were incubated at $37^{\circ} \mathrm{C}$ in a humidified atmosphere containing $5 \% \mathrm{CO}_{2}$. All studies were performed in Mycoplasma-negative cells. All cell lines were obtained from ATCC and the European collection of cell cultures, ECACC via Sigma [38]. Verteporfin was purchased from Sigma Aldrich, diluted in DMSO and the aliquots were stored at $-20^{\circ} \mathrm{C}$. Deslanoside and Digoxin were purchased from Sigma Aldrich. All treatments, including verteporfin were performed in dark conditions, to avoid any issue due to the photosensitivity of this molecule [39].

\subsection{Cell Viability Assay}

A growth inhibition assay was performed to assess cell viability. Cells were seeded in 24-well plates at a density of $5 \times 10^{5}$ cells per well. After $24 \mathrm{~h}$, cells were exposed to increasing concentrations of the compounds for 18 and $48 \mathrm{~h}$. 3-(4,5-dimethylthiazol-2-yl)2,5-diphenyltetrazolium bromide reagent (MTT) (Sigma Aldrich) was added to the cells at a final concentration of $0.5 \mathrm{mg} / \mathrm{mL}$, and then the cells were incubated for $4 \mathrm{~h}$ at $37^{\circ} \mathrm{C}$ in a humidified incubator with $5 \% \mathrm{CO}_{2}$, until purple precipitates were visible. The medium was removed, and the cells were washed once with PBS. To dissolve the formazan precipitates, DMSO was added to each well and the absorbance was read at $\mathrm{OD}=535 \mathrm{~nm}$. The drug concentration resulting in $50 \%$ inhibition of cell growth $\left(\mathrm{EC}_{50}\right)$ was calculated.

\subsection{Dual Luciferase Reporter Assay}

Twenty-four hours before the transfection, HaCat cells were seeded into 24-well plate $\left(5 \times 10^{5}\right.$ cells/well). The day after, the cells were transiently co-transfected with pGL4 Firefly luciferase 'experimental' vector (125 ng) (Promega), in which was inserted a YAP/TEAD response element (YRE; 8XGT-IIC lux) at the level of the upstream promoter of luciferase gene; pGL4 Renilla luciferase 'control' vector (10 ng) (Promega) and YAP expressing plasmid 'activator' plasmid (42 ng), using Lipofectamine 2000 Reagent (Invitrogen). After twenty-four hours from the transfection, the cells were treated with the compounds for $18 \mathrm{~h}$. The concentrations used for the treatment were the $\mathrm{IC}_{50}$ for each compound derived from the cell viability assay at $48 \mathrm{~h}$. Verteporfin was used as a ref- 
erence compound. The dual luciferase reporter assay was performed according to the manufacturer's instructions (Promega).

\subsection{Immunoblotting}

Cells were washed twice in ice-cold phosphate-buffered saline (PBS) and then lysed in RIPA Lysis Buffer (1\% sodium deoxycholate, $20 \mathrm{mM}$ Tris- $\mathrm{HCl}$ (pH 7.6), $150 \mathrm{mM} \mathrm{NaCl}$, $1 \%$ NP-40, 1 mM EGTA, 1 mM Na 2 EDTA, 1 mM Na $3 \mathrm{VO}_{4}, \mathrm{Na}_{2} \mathrm{MoO}_{4}, 1 \mathrm{mM}$ PMSF and protease inhibitor cocktail) (Sigma-Aldrich Corporation). The resulting suspension was centrifuged for $30 \mathrm{~min}, 14,000 \mathrm{rpm}$ at $4{ }^{\circ} \mathrm{C}$. The supernatant was collected, and the protein concentration was determined using Bradford Reagent (Sigma Aldrich). Cell lysates were incubated with $4 \times$ SDS sample buffer for $5 \mathrm{~min}$ at $100{ }^{\circ} \mathrm{C}$ and then were run on SDS-PAGE gels and transferred to PVDF membranes. Western blot analysis was performed using anti-YAP (clone 4D11.1, Millipore, dilution 1:1000), anti phospho-YAP Ser127 (clone D9W2I, Cell signaling, dilution 1:1000), and anti-Actin (clone C4, Millipore, dilution 1:2500). Protein bands were detected by enhanced chemiluminescence (ECL, GE Healthcare). Band density was calculated by using Image J software.

\subsection{Immunofluorescence Staining}

HT29 cells were seeded in multi 24-well plates $\left(5 \times 10^{5}\right.$ cells/well) and the day after were treated with the compounds for $24 \mathrm{~h}$. Cells were fixed for $10 \mathrm{~min}$ in $4 \%$ paraformaldehyde (PFA). The fixed cells were permeabilized with $0.3 \%$ Triton X-100 in PBS for 2 min on ice. After blocking in 3\% BSA for 30 min, slides were incubated with the first antibody diluted in $1 \%$ BSA for $1.5 \mathrm{~h}$. After washing with PBS, the slides were incubated with Alexa Fluor 568-conjugated secondary antibodies (1:1000 dilution) for $1.5 \mathrm{~h}$. Nuclei were stained with DAPI for $3 \mathrm{~min}$. Then, the slides were washed and mounted with antifade reagent (Vectashield, Vector Laboratories-H1000).

\subsection{Real Time PCR ( $q P C R)$}

Total RNA was extracted using Triazol Reagent and a PureLink RNA Mini Kit, the miRNeasy Mini Kit (Invitrogen), according to the manufacturer's instructions. Reverse transcription was performed with $0.5 \mu \mathrm{g}$ of total RNA using SuperScript first-strand, synthesis for RT-PCR (Invitrogen). The cDNA strand generated was used for PCR amplification in a total volume of $20 \mu \mathrm{L}$. Real-time PCR was performed with $100 \mathrm{ng}$ of cDNA using the Power SYBR green PCR master mix (Applied Biosystems). Samples were amplified in a CFX96 Touch ${ }^{\text {TM }}$ Real-Time PCR Detection System. Each sample was run independently in triplicate. The amplified were analyzed using Biorad CFX software. For each sample, three replicates were acquired, and Student's $t$ test was performed to evaluate statistical significance. The amount of target genes expressed was normalized using r18s.

\subsection{Statistical Analysis}

All data were obtained using the mean of three experiments. Statistical analysis was performed by using an unpaired $t$-test. A $p$-value of $<0.05$ was considered significant. Analyses were performed using GraphPad Prism v7 (La Jolla, CA, USA).

\section{Results}

\subsection{Chemical Library Collection}

With the goal of identifying YAP-TEAD inhibitors in a timely and cost-effective manner, and tailoring them for further development, we assembled a small chemical library of 27 entries, selected from a collection of about 2000 compounds within the databases of our academic laboratories. We included a few commercial compounds, such as pristimerin, digoxin, deslanoside, and verteporfin with known connection with the Hippo pathway. The chemical structures of the included compounds are reported in Table S1 (Supplementary Materials), whereas the main scaffolds are depicted in Figures S2-S14. The library size was restricted to lead-like compounds based on: (i) chemical diversity, (ii) potential connection 
established by the compounds' target with YAP-TEAD and the Hippo pathway activity, and (iii) structural features suitable for PPI inhibition. This allowed us to provide a reasonable coverage of chemical space (see Section 3.2), and high-quality starting points (available information on synthesis, physico-chemical properties and bioassay data) for further optimization studies. To develop a more tailored selection and to examine the connection to YAP-TEAD and Hippo pathway activity (point ii), we performed a metadata analysis, reported in detail in the Supplementary Materials (pages 3,4), in which the biological activity of all compounds was described. Then we cross-examined the networks of PPI (interactome) of the biochemical and functional distances between the core proteins of the Hippo pathway (TEAD1-4, LATS1/2, YAP1, MOB1A, MOB1B, STK4, SAV1), representing the neighbor upstream kinome of YAP (Figure 1), and the compounds' target. With this aim, we adopted suitable bioinformatic tools such as STRING www.string-db.org, accessed on 25 January 2022) and PANTHER (www.pantherdb.org, accessed on 25 January 2022). This work was preliminary to the compound selection and is reported in detail in Figures Supplementary Materials File 1. On the basis of the predicted interactome generated with the Hippo pathway components, it was possible to obtain three groups from the selected library, helping in a further reduction of the library.

Our library includes registered drugs ( 7\%) and approximately 93\% preclinical compounds coming from in-house molecular design expertise and synthesis efforts in various drug discovery projects (Table S1, Supplementary Materials). Particular attention was given to the presence of hydrophobic, rigid, and aromatically-privileged scaffolds, able, in principle, to modulate PPI $[40,41]$. The chemical library collected for the cell-based screening assay included different chemotypes having a common scaffold close to molecules known to be able to act either directly or indirectly on the terminal effectors YAP/TAZ and TEAD of the Hippo signaling pathway.

All compounds had never been studied in the context of the Hippo pathway. The compounds selected for the library carry structural features such as those reported in the iPPI-DB database containing protein-protein interactions modulators (https:/ /ippidb. pasteur.fr, accessed on 25 January 2022) [27].

\subsection{Chemoinformatic Analysis: Physicochemical Descriptors and PCA}

A chemoinformatic in silico analysis was performed to characterize the physical and chemical properties of the 27-compound collection using the QikProp module of the Canvas 3.2 platform. Verteporfin and dasatinib were added to the library as reference compounds with a known biological profile in YAP-TEAD activity modulation. For each molecule, the calculated descriptors Molecular Weight (MW), AlogP, number of H-bond acceptors (HBA) and H-bond donors (HBD), Topological Polar Surface Area (TPSA), and number of Rotatable Bonds (RBs) were analyzed (Table S2 and Figure S2 in Supplementary Materials). The MW of the compounds ranged from $206 \mathrm{~g} / \mathrm{mol}$ to $1344 \mathrm{~g} / \mathrm{mol}$. The calculated lipophilicity (AlogP) ranged from -1.18 to 9.05. The number of HBA was 0-19; whereas the number of HBD varied from 0 to 9 . Extending the $\mathrm{RO} 5$ evaluation to include properties associated with favorable bioavailability, the library showed a TPSA in the range 24-282 $\AA^{2}$, with between 1 and 28 rotatable bonds, with a mean of 8.4. Figure S2 shows the distribution of the parameters in the library, and assuming no more than one violation of the rule, $51.7 \%$ of the entire library resulted as in accordance with Lipinski's 'rule of five (RO5)' [42]. Therefore, the library contains compounds that show drug-like properties; thus, being useful for further studies in the hit-to-lead phase.

Principal component analysis (PCA) was performed for evaluating the chemical space coverage of our molecule collection as a function of the six physicochemical properties previously defined. In PCA analysis, each principal component (PC) is a linear combination of all original variables involved, and PCs are defined in such a way that the variance of the scores is maximal. Based on the screen-plot in Figure S3, reporting the total amount of variance explained by each single PC (eigenvalue), it was possible to show that the first two PCs cumulatively retrieved $87.2 \%$ of the variance. By setting $80 \%$ as the threshold of 
total variance, they are, hence, suitable for giving a comprehensive representation of the relationships between the variables of the entire original dataset $[43,44]$. Considering the loading value of each single variable [44], it was possible to show that the MW and TPSA variables had the highest contribution to defining PC1 (significant correlation $\geq \pm 0.50$ ), while AlogP had a negligible role in explaining the variation due to PC1; in the same way, PC2 resulted as strongly correlated with AlogP and RBs, whereas the remaining variables had a lesser relevance for assessing the variation due to this principal component. Table S3 (Supplementary Materials) summarizes the loading values for all six original properties. In Figure 3, the PCA scores of the entire chemical collection are shown as a score-plot, displaying a 2D-visual representation of the chemical space with identification of compound clusters based on complexity structure similarities, alongside the variable correlations. In our specific case, the PCA results were mapped using a traffic-light system, from blue (low complexity) to bright red (high complexity), with moderately complex molecules in violet-purple. Based on the results, it was possible to determine that the original database consisted of more blue-to-purple chemical entries; therefore, revealing a medium-high level of molecular complexity for our selected compound library.

\section{PC Score plot}

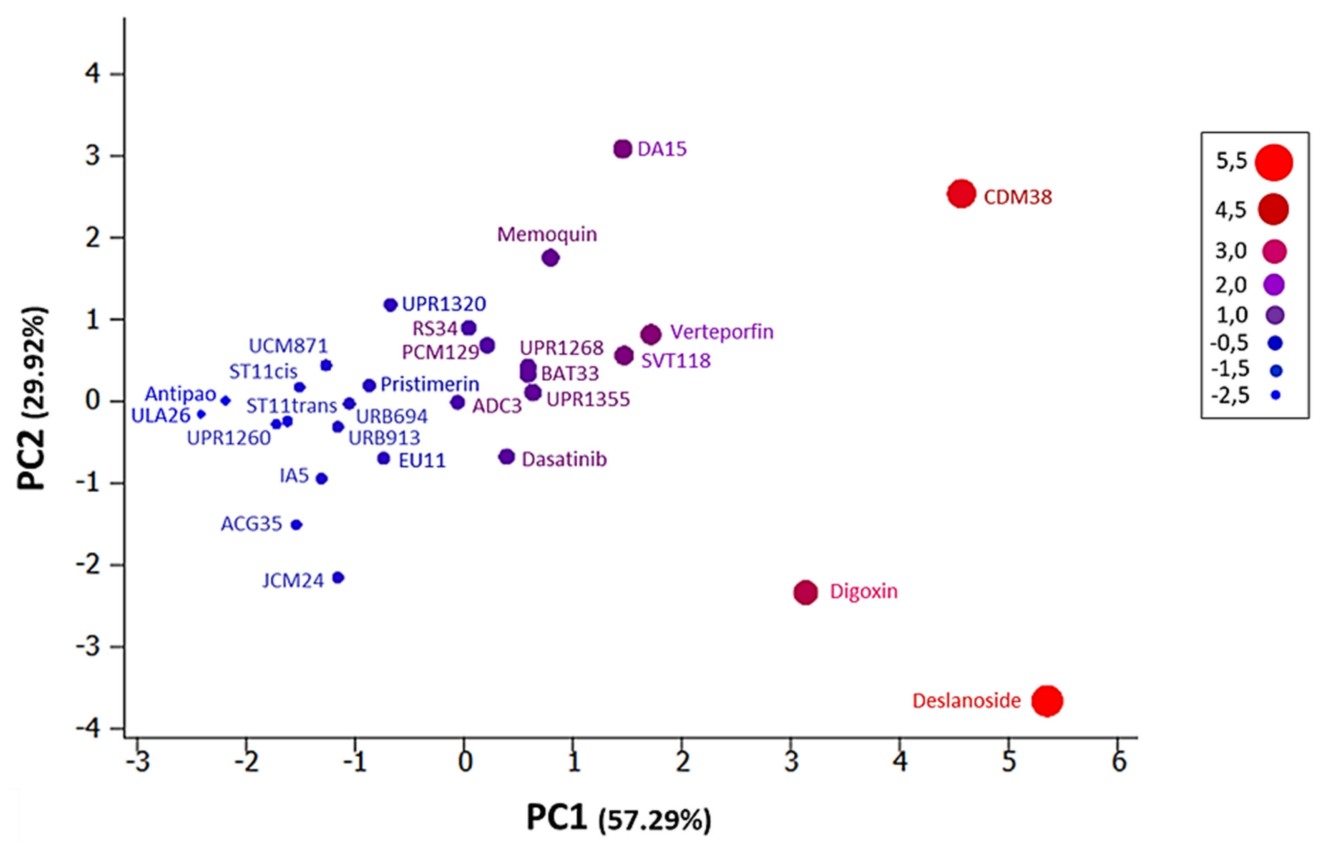

Figure 3. PC score-plot. This graph shows the PCA scores of the entire chemical collection, represented by a traffic-light system. Each dot refers to a single compound. Verteporfin and dasatinib were included in the original dataset as reference compounds. Based on the PC1 mapping distance (from -3 to +6 ), the library covers different regions of the chemical space. Deslanoside, CDM38, and digoxin share very similar physicochemical properties, while they are strongly dissimilar with respect to compounds located at opposite sides of PC1 (i.e., Antipao and ULA26). Based on the mapping of PCA scores, the original database consists of more blue-to-purple chemical entries (medium-high level of molecular complexity), and five main clusters were identified: cluster 1 (blue): antipao, ULA26; cluster 2 (persian blue): UCM871, ST11cis, ST11trans, UPR1260, IA5, ACG35, JCM24; cluster 3 (navy blue): EU11, pristimerin, UPR1320, URB694, URB913; cluster 4 (violet-purple): memoquin, ADC3, RS34, PCM129, UPR1355, BAT33, UPR1268, dasatinib, DA15, SVT118, verteporfin; cluster 5 (magenta-cherry-red): digoxin, CDM38, deslanoside.

Based on the map-distance, our library spans different regions of the chemical space in the $2 \mathrm{D}$ reference frame. In this graph, single dots located at opposing region of the score plot correspond to chemical compounds being strongly dissimilar and occupying different 
and far away regions of the chemical space. Based on the distribution of PCA scores, it was possible to identify five main compound clusters, occupying similar regions of the chemical space. The five identified clusters are the following: cluster 1 (blue): antipao, ULA26; cluster 2 (persian blue): UCM871, ST11cis, ST11trans, UPR1260, IA5, ACG35, JCM24; cluster 3 (navy blue): EU11, pristimerin, UPR1320, URB694, URB913; cluster 4 (violet-purple): memoquin, ADC3, RS34, PCM129, UPR1355, BAT33, UPR1268, dasatinib, DA15, SVT118, verteporfin; cluster 5 (magenta-cherry-red): digoxin, CDM38, deslanoside.

In addition, aiming to identify putative core structures shared by the molecules populating the entire collection, a similarity-based hierarchical-clustering analysis was performed. Sixteen compound clusters were first identified based on functional type and hybridization grade of atoms and bonds, respectively. Among these, four clusters were singlet clusters, while the molecules populating the remaining 12 clusters were further visually inspected, and compound groupings sharing the same chemical corestructure were grouped together: $\mathrm{i}-3$-vinylpyridine; ii-1,3-dimethoxybenzene; iii-2,5diamino-cyclohexa-2,5-diene-1,4-dione; iv-N-(2-((3-methoxy-phenyl)amino)ethyl)acetamide; v-phenol; vi-chlorobenzene; vii-6,7-dimethoxyquinazoline-2,4-diamine; viii-acridin-9amine; ix-1H-pyrrol-1-amine; $x-1 H$-indole; $x i-5 \alpha, 14 \alpha$-androstane; $x i i-m e t h y l c y c l o h e x a-2,4-$ dienecarboxylate (Figure 4). We also performed a similar analysis using the DenovoProfiling webserver (http: / / denovoprofiling.xielab.net, accessed on 20 November 2021), which provides structural identification and chemical space exploration relative to compounds in the public database, i.e., PubChem, and the collected results were very similar (data not shown). The compound collection was then analyzed in details in the following sections [45-66].

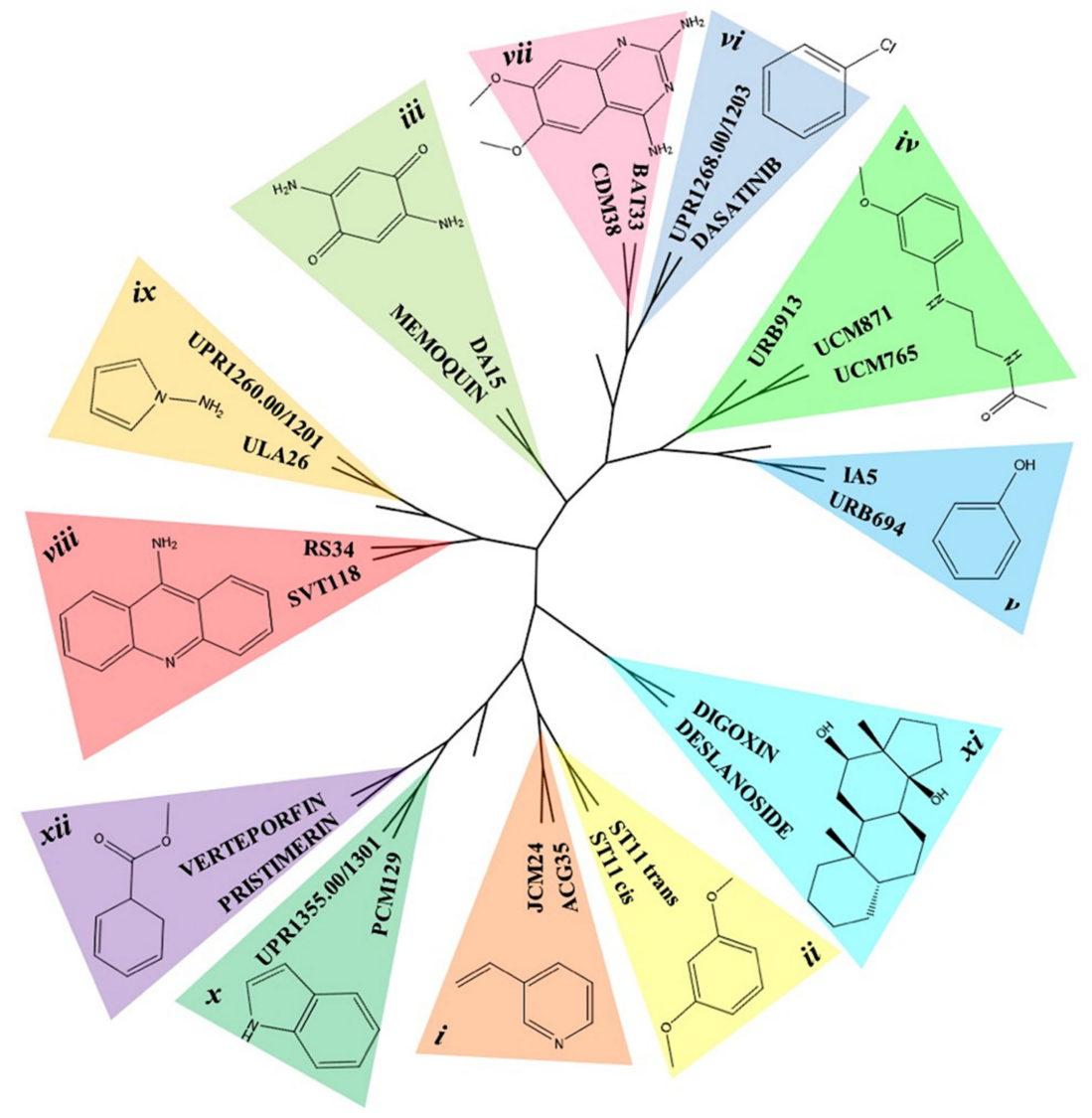

Figure 4. TreeMap. This figure summarizes the clusters identified from the hierarchical clustering analysis. The chemical core-structures and the compounds populating each cluster are shown.

\subsection{Chemistry}

Most of members of the in-house library were not resynthesized, and their synthetic and characterization data are reported in their respective publications (quinones: memo- 
quin [45], SVT118 [46], IA5 [48], EU11 [66]; quinazolines and quinolines (CDM38, BAT33, UPR1268) [49-51]; stilbenes (ST11 cis/trans) [52]; thiazolidindione (ACG35) [53]; diketopiperazine (JCM24) [54]; tetrahydroacridine (RS34) [55]; dibenzodiazepinone (ADC3); carbazole (ULA26) [56]; steroids (pristimerin, PCM129, UPR1355, digoxin, deslanoside) [57,60-62]; carbamates (URB694, URB913) [58,59]; anilino-alkyl-amides (UCM765, UCM871) [63,64] (Figure 2). One of the selected compounds (DA15) is unpublished, and we report the synthetic procedure below. As depicted in Scheme 1, amine 2 was obtained through the reductive amination of 2-(benzyloxy)benzaldehyde with ethylamine. Then, the nucleophilic substitution reaction between 2 and $\mathrm{N}$-(6-bromohexyl)phthalimide afforded compound 3 . Removal of the phthalimide protecting group was performed, with hydrazine leading to the deprotected primary amine 4 , which was then reacted with 2,5-dimethoxy-1,4benzoquinone, providing 1 (DA15) in a good yield (85\%). $\mathbf{1}^{\prime}$ identity was confirmed by analytical (HPLC), full scan MS (ESI+), and spectroscopic data (NMR, see reported spectra in Supplementary Materials).

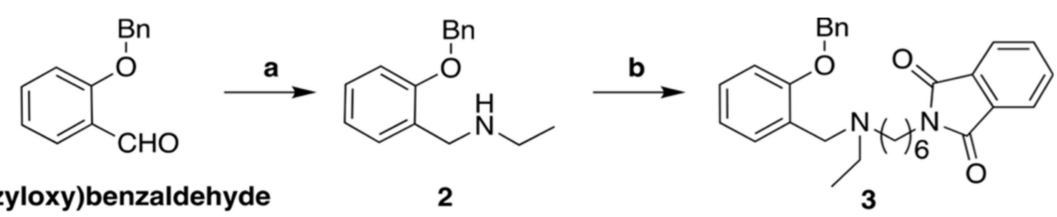
3<smiles>CCN(CCCCCCNC1=CC(=O)C(NCCCCCCN(CC)Cc2ccccc2OCc2ccccc2)=CC1=O)Cc1ccccc1COc1ccccc1</smiles>

Scheme 1. Synthetic procedure for synthesis of 1 (DA15). Reagents and conditions: (a) $\mathrm{CH}_{3} \mathrm{CH}_{2} \mathrm{NH}_{2}$, $\mathrm{NaBH}_{4}$, toluene, room temperature, $72 \%$; (b) $\mathrm{N}$-(6-bromohexyl)phthalimide, $\mathrm{KI}, \mathrm{DMF}, 90{ }^{\circ} \mathrm{C}, 50 \%$; (c) $\mathrm{NH}_{2} \mathrm{NH}_{2} \bullet \mathrm{H}_{2} \mathrm{O}, \mathrm{EtOH}$, reflux, 88\%; (d) 2,5-dimethoxy-1,4-benzoquinone, EtOH, $60{ }^{\circ} \mathrm{C}, 85 \%$.

\subsection{Identification of Compounds with the Potential to Inhibit Cell Growth}

To identify efficient cell growth inhibitors, we screened the chemical library of 27 compounds (Table S1, Supplementary Materials) with the Human Keratinocyte cell line (HaCaT). The $\mathrm{HaCaT}$ cell line has a high capacity to proliferate and differentiate in vitro and is widely used for Hippo pathway studies. HaCaT cells were treated with all compounds at several concentrations (0.1-20 $\mu \mathrm{M})$ for 18 and $48 \mathrm{~h}$ (Figures S4 and S5, in Supplementary Materials, respectively), and the corresponding $\mathrm{IC}_{50}$ values were measured by performing an MTT assay (Tables S3 and S4, Supplementary Materials). To select active compounds (Table 1), we evaluated the $\mathrm{IC}_{50}$ at $48 \mathrm{~h}$, while we considered the $\mathrm{IC}_{50}$ at $18 \mathrm{~h}$, to ensure a high percentage of viable cells, necessary for the YAP-TEAD complex activity study, described below. In Figure 5, we show the growth inhibition effects of the compounds that at $10 \mu \mathrm{M}$ reduced cell viability, within a range of $\mathrm{IC}_{50}$ between 0.2 and $7.3 \mu \mathrm{M}$ at $48 \mathrm{~h}$ (Table 2). Three of these compounds, digoxin, deslanoside, and pristimerin, showed activity at nanomolar concentrations ( $\mathrm{IC}_{50}$ values: $0.20,0.25$ and $0.80 \mu \mathrm{M}$, respectively, Table 2), and the other four compounds (IA5, DA15, memoquin, and UPR1268), inhibited cell growth at concentrations lower than $8 \mu \mathrm{M}$. 
Table 1. Chemical structures and known biological activities of the selected compounds.
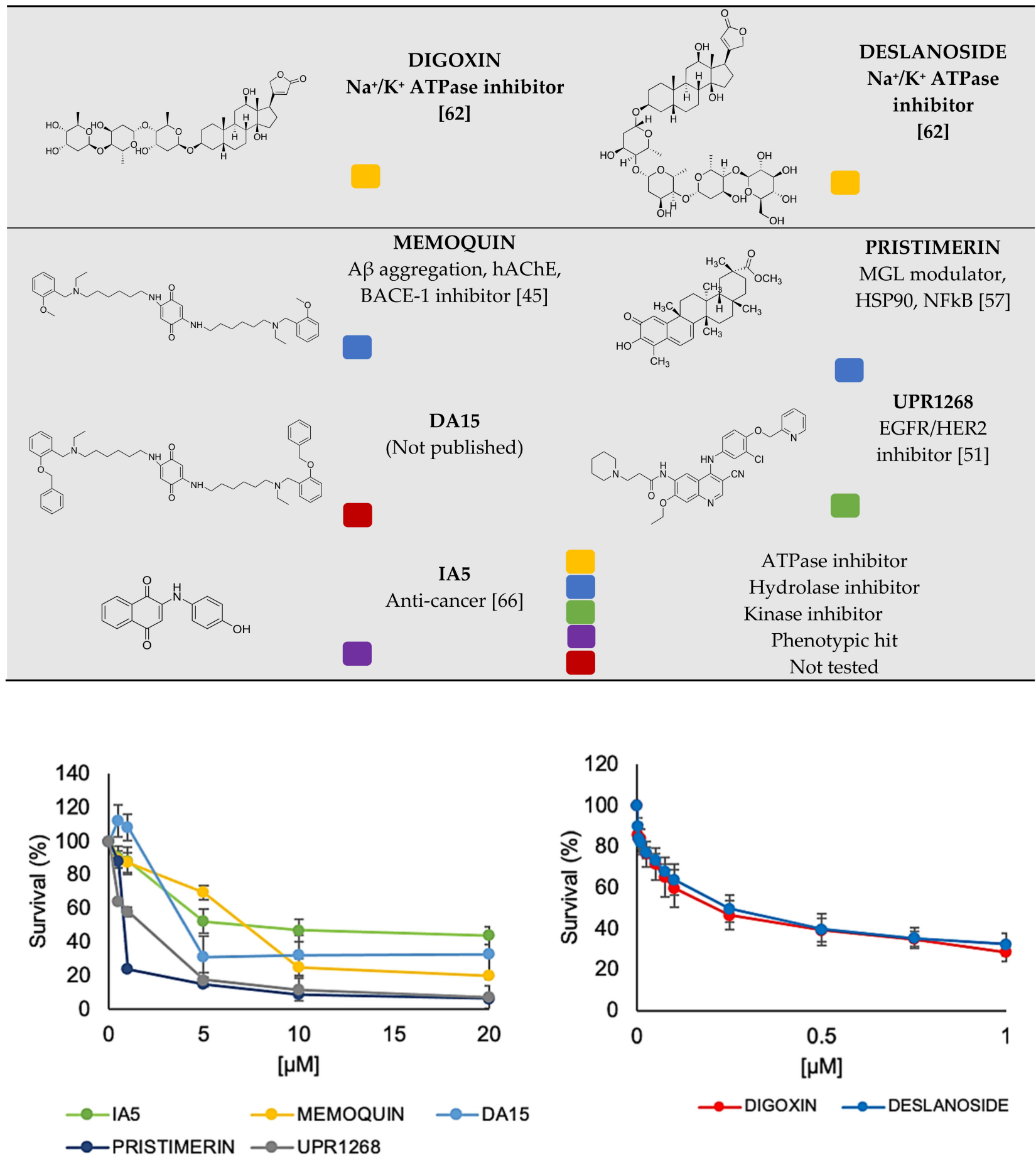

Figure 5. MTT assay of the selected compounds in HaCaT cells after $48 \mathrm{~h}$ of treatment. Left: dose dependent inhibition of the most active compounds showing an $\mathrm{IC}_{50}$ below $10 \mu \mathrm{M}$. Right. compounds showing an $\mathrm{IC}_{50}$ at nanomolar concentration. Error bars represent s.d. $(\mathrm{n}=3)$. 
Table 2. Cytotoxic effect of the seven selected compounds against several cancer cell lines using an MTT assay.

\begin{tabular}{cccccc}
\hline \multicolumn{7}{c}{ IC $_{\mathbf{5 0}}(\boldsymbol{\mu M})$-Cancer Cell Lines $\mathbf{( 4 8}$ h) } \\
\hline Compound & $\mathbf{A 2 7 8 0}$ & $\mathbf{A 2 7 8 0 / C P}$ & HCA46 & HT29 & HCT116 \\
\hline VERTEPORFIN & $12.38 \pm 2.15$ & $12.3 \pm 0.76$ & $5.55 \pm 1.2$ & $3.1 \pm 0.32$ & $14.7 \pm 2.79$ \\
\hline MEMOQUIN & $9.53 \pm 0.81$ & $14.03 \pm 1.05$ & $14.59 \pm 0.7$ & $9.82 \pm 0.8$ & $2.89 \pm 0.08$ \\
\hline IA5 & $3.8 \pm 1.06$ & $5.35 \pm 0.95$ & $19.79 \pm 4.0$ & $2.68 \pm 0.72$ & $4.17 \pm 1.94$ \\
\hline UPR1268 & $6.17 \pm 0.71$ & $4.5 \pm 1.7$ & $2.39 \pm 0.3$ & $4.81 \pm 0.25$ & $6.79 \pm 0.39$ \\
\hline DA15 & $1.71 \pm 0.12$ & $2.04 \pm 0.66$ & $>2.5$ & $1.78 \pm 0.46$ & $1.59 \pm 0.45$ \\
\hline PRISTIMERIN & $0.44 \pm 0.03$ & $0.19 \pm 0.01$ & $0.94 \pm 0.4$ & $0.8 \pm 0.2$ & $0.64 \pm 0.15$ \\
\hline DIGOXIN & $0.06 \pm 0.01$ & $0.04 \pm 0.0$ & $0.38 \pm 0.15$ & $0.04 \pm 0.01$ & $0.08 \pm 0.0$ \\
\hline DESLANOSIDE & $0.1 \pm 0.03$ & $0.05 \pm 0.0$ & $0.19 \pm 0.03$ & $0.07 \pm 0.0$ & $0.12 \pm 0.01$ \\
\hline
\end{tabular}

The most active compounds were progressed to further studies (Figure 2). Among the seven active compounds, three quinones [45,66], one quinoline [51], and three steroid derivatives [57,62] were included. Remarkably, quinones, such as memoquin, DA15, IA5, or quinolines, such as UPR1268, were pinpointed as inhibiting PPI, by abolishing pivotal $\pi-\pi$ or $\pi$-cation interactions, deemed to be the hot spots for protein-protein interface formation [40], or by bearing multiple aromatic rings and conformational stiffnesses [41]. Quinone, bearing a polyamine backbone (i.e., memoquin or DA15), has an additional chance of recognizing multiple anionic sites of the protein-protein interface by assuming different protonated conformations.

Chemical entities belonging to the steroid class, such as the triterpenoid pristimerin [57] has demonstrated antiproliferative properties. Pristimerin is known to inhibit cell invasion, migration, and proliferation in colon cancer cells [67], while UPR1268 is effective against malignancy transformation and progression, through pathways inferred from the literature [65] in gefitinib-resistant non-small-cell lung cancer [68]. Cardiac glycosides (such as digitoxin [24]) can promote the nuclear translocation of YAP in YAP low-level oncotypes [69], and decrease the relative ratio of pYAP to total YAP in cancer cell lines [24]. As previously suggested in a computational model by Sudol et al. [23], the binding site of this class of molecules was predicted to be at the WW1 domain level, with subsequent displacing of cytoplasmic inactivators [13]; however, the mechanism is still unclear. Based on this information, the selected compounds showed potential for more specific YAP-TEAD modulation studies.

\subsection{Inhibition of the Activity of the YAP-TEAD Complex}

We next tested the compounds' ability to specifically modulate YAP-TEAD activity. We performed a specific gene-reporter assay based on Luciferase signal variation detection [69]. By cloning a YAP responsive element upstream, the promoter sequence of Luciferase reporter gene, it was possible to evaluate the ability of the selected YAP-target compound library, to modulate gene transcription [70]. First, we co-expressed pGL4 Firefly luciferase, pGL4 Renilla luciferase, and YAP plasmids in HaCaT cells, widely used for Hippo pathway studies, and after $24 \mathrm{~h}$ we treated the cells with IA5, DA15, memoquin, UPR1268, pristimerin, digoxin, and deslanoside for $18 \mathrm{~h}$, at their $\mathrm{IC}_{50}$ value calculated at $48 \mathrm{~h}$. VP, known to disrupt YAP-TEAD complex at $18 \mathrm{~h}$ in uveal melanoma cells, was used as a reference compound in all experiments [16,71,72]. We found a reduction of the luciferase activity, showing a significant decrease of the YAP-TEAD complex activity after the treatment with the selected compounds, comparable with the reference molecule, VP (Figure 6). These results may be an important step in studying how these compounds would affect the YAP-TEAD activity in cancer cells. 
A

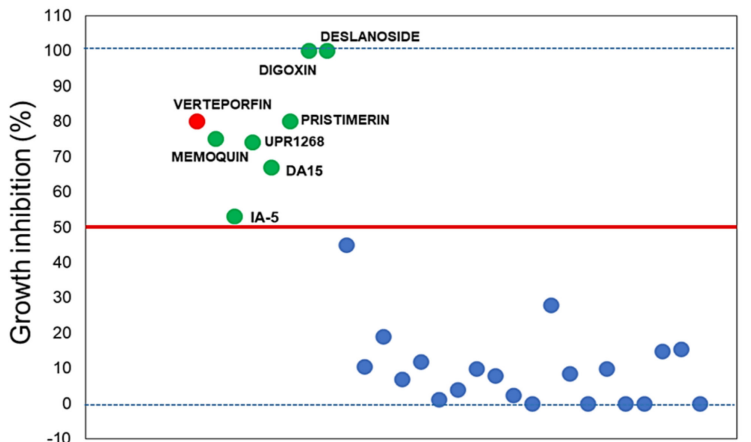

B

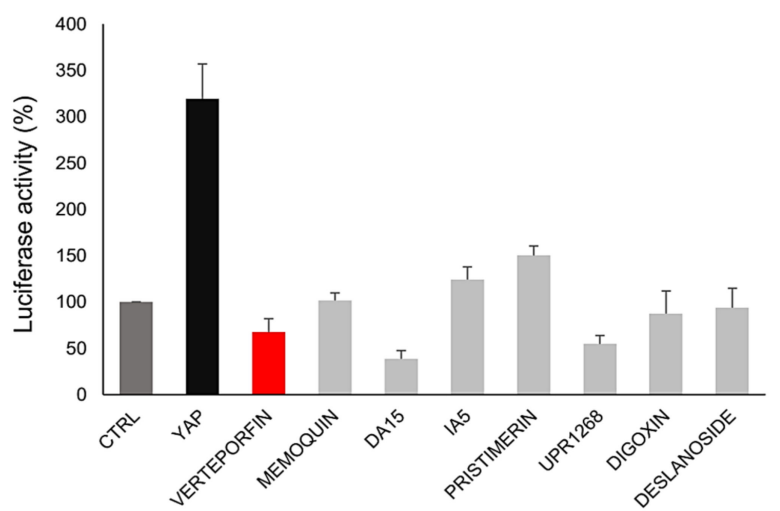

Figure 6. HaCaT cell growth inhibition and luciferase assay. (A) Plots showing growth inhibition of $\mathrm{HaCaT}$ cells treated with a library of compounds at $10 \mu \mathrm{M}$. Verteporfin (reference compound) is highlighted in red and the active compounds in gray. Blue dots represent compounds with no effect on the proliferation. (B) Detection of YAP-TEAD activity by luciferase assay after $18 \mathrm{~h}$ of treatment. Verteporfin was used as reference drug (red bar). YAP1/3 indicates the ratio between the YAP plasmid (activator) and pGL4/hRluc plasmid (experimental vector). Error bars represent s.d. $(\mathrm{n}=3)$.

\subsection{Cancer Cell Growth Inhibition and YAP Protein Levels and Phosphorylation Changes}

Much evidence highlights that YAP-TEAD activity is essential for cancer initiation and the growth of most solid tumors [1,7]. To assess the inhibitory effect of our compounds on cancer cells, we selected three colon cancer cell lines (HCA46, HCT116, and HT29), and two ovarian cancer cell lines (A2780 and A2780/CP). It has been reported that cell proliferation is affected by YAP knockdown [3,73], and, therefore, the experiments proposed had the rationale of addressing the potential capacity of the tested compounds to modulate YAP-TEAD activity. Cancer cells were treated for $48 \mathrm{~h}$ with various concentrations of the compounds, followed by MTT assay. Most of the compounds inhibited the cell growth, as shown in Table 2. Digoxin, deslanoside, and pristimerin showed $\mathrm{IC}_{50}$ values at nanomolar concentrations. IA5, DA15, memoquin, and UPR1268 inhibited cell growth in all cancer cell lines, showing an $\mathrm{IC}_{50}$ value between 1 and $14 \mu \mathrm{M}$.

To study the effects of our compounds in colorectal cancer cells, in which YAP plays a crucial role in the aggressiveness and metastasis [74], we first identified the protein expression profiles of YAP and its phosphorylated form at Ser127 residue, in a panel of colon cancer cell lines (SW116 and HCA46 sensitive to Fluorouracil (5FU), LoVo, Caco2, HT29 and HCT116 less sensitive to 5FU) (Figure 7A). Western blotting analysis showed that YAP protein levels were differently expressed in these cell lines, as well as their phosphorylation (Figure 7A). To evaluate whether our molecules might affect the YAP and pYAP-Ser127 protein level, HT29 cells were treated with the selected compounds for $24 \mathrm{~h}$ at their $\mathrm{IC}_{50}$ values. The compounds IA5, UPR1268, digoxin, and deslanoside reduced the total YAP and pYAP-Ser127 protein levels, DA15 increased the total YAP protein levels but not its phosphorylated form (pYAP-Ser127), and memoquin enhanced both the total 
YAP protein and pYAP-Ser127 (Figure 7B,C). Since YAP phosphorylation at Ser127 residue is an important indicator of YAP function activity and its subcellular localization, the ratio between pYAP-Ser127 and total YAP was quantified as well (Figure 7D). Notably, we found that IA5 increased the levels of pYAP-Ser127/YAP ratio, indicating that this compound might promote the cytoplasmic YAP retention, with a consequent reduction of nuclear YAP translocation and its activity. All other compounds, such as the reference compound verteporfin, showing a reduction of YAP-TEAD activity in luciferase assay, unexpectedly exhibited a reduction of pYAP-Ser127/YAP ratio (Figure 7D). This prompted us to hypothesize that they might modulate the protein YAP amount/activity with a different mechanism of action with respect to IA5 compound.

A

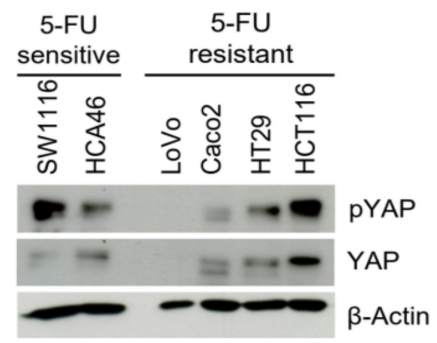

C

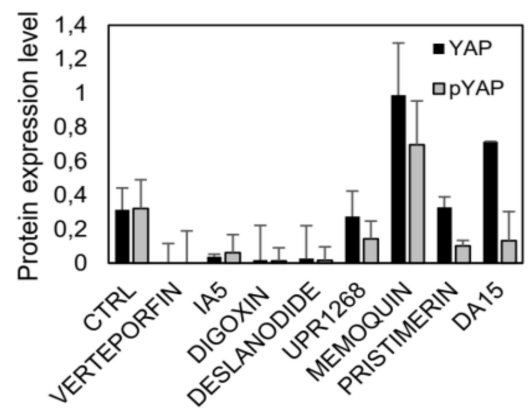

B

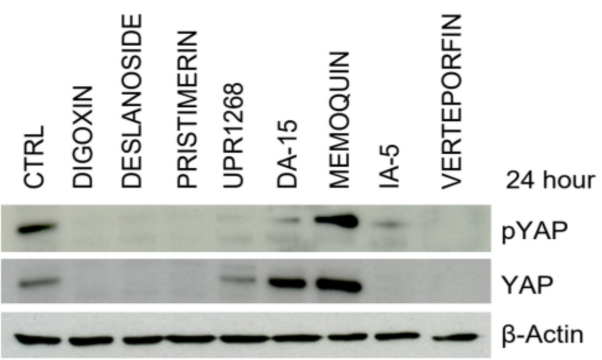

D

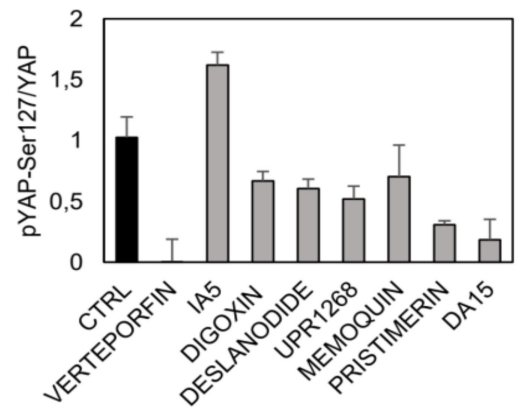

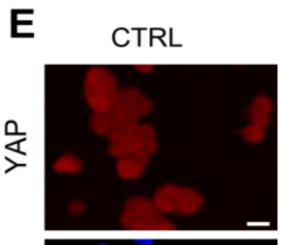

VERTEPORFIN

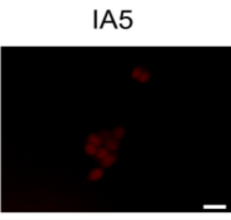

DESLANOSIDE

DIGOXIN
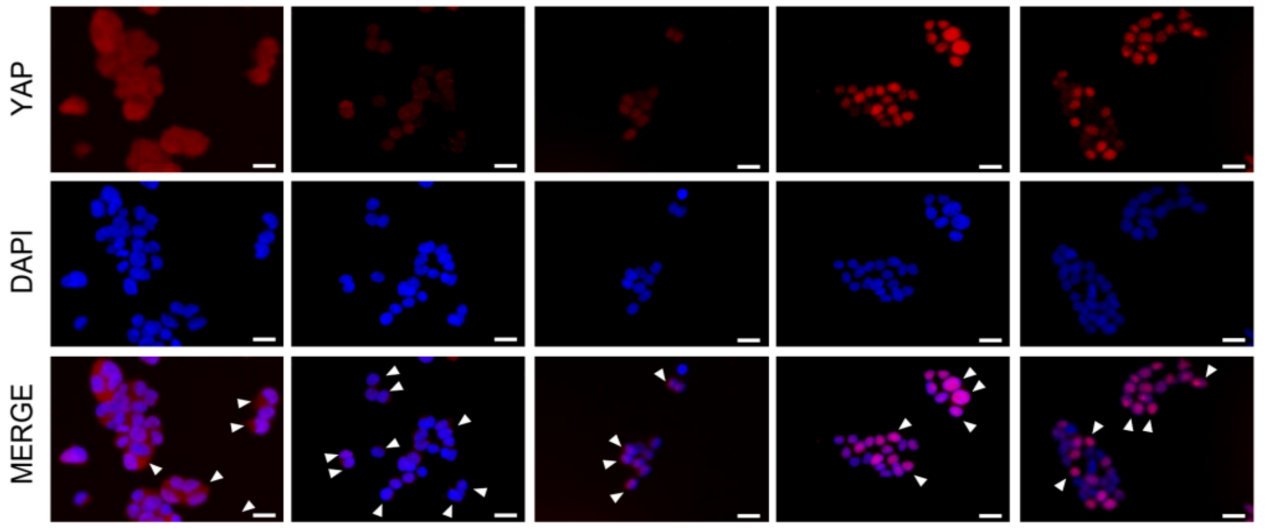

Figure 7. Effects of the compounds on YAP protein levels and phosphorylation status in cancer cell lines. (A) Western blotting, showing the basic level of YAP and pYAP-Ser127 levels in a panel of colorectal cancer cell lines; (B) protein expression levels of YAP and pYAP-Ser127 after treatment of HT29 cells with the selected compounds (short-exposure blots were used as a representative image); and $(\mathbf{C})$ the corresponding densitometric quantification; (D) quantification of pYAP-Ser127/YAP ratio; (E) immunofluorescent staining of YAP protein after $24 \mathrm{~h}$ of treatment with the relative compounds. Verteporfin was used as a reference compound. Error bars represent s.d. $(\mathrm{n}=3)$. Scale bars $25 \mu \mathrm{m}$. 
Furthermore, we confirmed the effect of IA5 on the YAP protein levels, by using immunofluorescence staining in HT29 cells. The HT29 cells were treated with IA5 and all other compounds for $24 \mathrm{~h}$ (Figure 7E). The results showed a significant decrease of the YAP protein level, both in the nucleus and in the cytoplasm, compared with the verteporfin treatment. Digoxin and deslanoside, as well as digitoxin in a previous study [69], promoted YAP nuclear retention, agreeing with the attenuated YAP-Ser127 phosphorylation level that we observed (Figure 7B-D). All other compounds did not display any significant variation of the YAP level with respect to control cells.

\subsection{IA5 Reduces YAP-TEAD Target Genes Expression}

Finally, to understand the mechanism by which our compounds inhibited the cell growth, we examined the expression levels of YAP mRNA and YAP-TEAD target gene expression in two colorectal cancer cell lines, HCT116 and HT29. The mRNA levels of YAP and of the two specific target genes, cysteine-rich angiogenic inducer 61 (CYR61) and connective tissue growth factor (CTGF), were evaluated using quantitative PCR (qPCR), in cells treated for $48 \mathrm{~h}$ (Figure 8). We found that the IA5, similarly to VP, induced a significant decrease of YAP mRNA level and its target genes, CYR61 and CTGF, in both HCT116 and HT29 cell lines, affecting the YAP-TEAD complex activity. These data are in accordance with the luciferase assay results (Figure $7 \mathrm{~B}$ ) and the phosphorylation variation of YAP protein (Figure 7B-D), suggesting that the IA5 compound might represent a potential candidate for cancer cell growth inhibition, by targeting the YAP-TEAD complex activity. Digoxin and deslanoside decreased the protein expression of YAP (Figure 7C) and increased CTGF and Cyr61 mRNA levels (Figure 8A). It is reasonable that in our experimental conditions, TAZ protein may have replaced YAP after its reduction. Indeed, YAP and TAZ are generally thought to be functionally redundant [75]. All other compounds did not show any significant reduction in the YAP mRNA levels and CYR61, CTGF target genes.

\section{A}

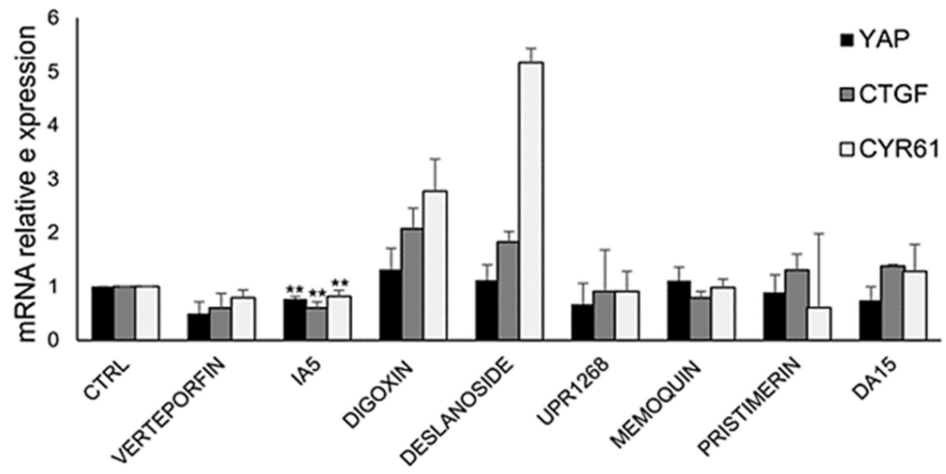

B

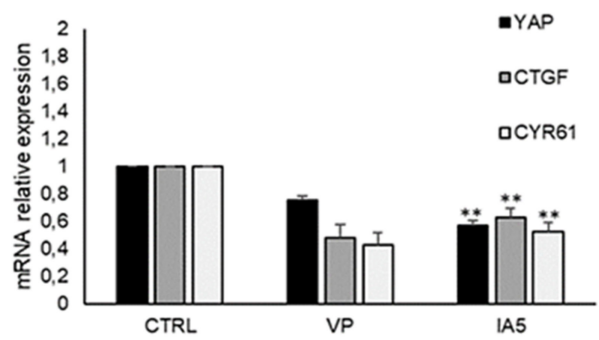

Figure 8. YAP mRNA levels and its target genes decreased after treatment with IA5 in colorectal cancer cells. (A) Histogram showing the effects of the seven selected compounds on HCT116 cells, and (B) histogram representing the quantification of mRNA level in HT29 cells treated with IA5. Verteporfin was used as a reference compound. Error bars represent s.d. $(\mathrm{n}=3) ;{ }^{* *} p$ value $<0.05$. 


\section{Discussion}

Since the YAP-TEAD complex is an interesting target in cancer, modulating the interaction of YAP/TAZ with transcriptional factor, TEAD, may be an effective strategy for cancer therapy [11]. Currently there are no clinically available drugs targeting the YAP/TAZ-TEAD interaction for cancer treatment. For this reason, following a repurposing strategy, in this study we collected and screened a library of 27 small molecules, supposed to modulate TEAD gene expression. In all experiments, we also included VP, the first small molecule reported as a YAP-TEAD disrupter $[17,76]$. First, a chemoinformatic in silico analysis was performed to characterize the physical and chemical properties of the 27-compound collection, using the Chemioinformatic platform. We could conclude that our compounds were characterized by a medium-high level of molecular complexity. The library was characterized by high molecular diversity, in which different clusters were identified. Then we evaluated the effect of these compounds on the cell viability in $\mathrm{HaCaT}$ cells, a model widely used for Hippo pathway studies, and measured the $\mathrm{IC}_{50}$ by MTT assay. Among these compounds, we selected seven out of 27, as able to inhibit the cell growth at low concentration. Next, we tested their capability to reduce the YAP-TEAD complex activity in cells, using an luciferase assay. We found that the tested compounds reduced the YAP-TEAD activity with respect to the control cells. It is well known that YAP plays an important role in regulating cell tumor proliferation [7], and its overexpression is associated with poor prognosis in cancer patients [4]. Consequently, we chose to evaluate the effect of the selected compounds on the YAP protein level, and YAP phosphorylation status in three colorectal cancer cell lines and two ovarian cancer cell lines. We found that the quinone derivative IA5 reduced the total YAP protein levels and increased the pYAP-Ser127/YAP ratio in HT29 cells, with respect to controls, indicating that IA5 might inhibit the nuclear YAP translocation, followed by a reduction of YAP-TEAD activity. This might be an important feature for a potential compound capable of targeting the YAPTEAD complex, inhibiting the cancer proliferation. Moreover, we found that digoxin and deslanoside reduced the total protein YAP, but also the pYAP-Ser127/YAP ratio, suggesting that they might operate similarly to digitoxin, inducing the YAP nuclear retention and enhancing YAP activity [69].

Furthermore, we confirmed the impaired YAP protein expression, and YAP intracellular localization, in HT29 cells using an immunofluorescence technique. The HT29 cells, after treatment with IA5, digoxin and deslanoside for $24 \mathrm{~h}$, displayed a drastic reduction of YAP protein when cells were treated with IA5 with respect to control cells, while the two digitoxin derivative molecules (digoxin and deslanoside) increased the YAP protein translocation into the nucleus. Notably, YAP interacts with TEAD in the nucleus and induces expression of genes involved in the regulation of cell growth, proliferation, and survival, including connective tissue growth factor CTGF and cysteine-rich angiogenic inducer 61, CYR61 [77]. Then, we examined the expression of these two YAP-TEAD target genes in two colorectal cancer cell lines (HCT116 and HT29), and, as expected, we observed that IA5 reduced the mRNA level of CYR61 and CTGF1, with respect to control cells. The reduction was comparable with the reference molecule, VP. This result may suggest IA 5 as a potential inhibitor of TEAD activity. Quinone moieties are widely distributed in nature and are the key pharmacophore referred to the 2-(4-hydroxyanilino)-naphthoquinone scaffold (quinone in Figure 2) of many clinically important anti-cancer drugs, such as anthracycline, daunorubicin, doxorubicin, mitomycin, mitoxantrones, and saintopin. Quinones are also known as highly redox active molecules, leading to the formation of reactive oxygen species (ROS), which can alter the redox balance within cells through the formation of oxidized cellular macromolecules, including lipids, proteins, and DNA; accounting at least in part, for the reduced viability of all our cell lines observed with the compounds, IA-5, digoxin, and deslanoside $[78,79]$. In addition, to reinforce this effect, it was also shown that inactivation of YAP decreases antioxidant gene expression, leading to enhanced oxidative stress-induced cell death through downregulation of catalase and MnSOD [80]. 
The putative interference behind the YAP-TEAD activity inhibition by IA5 might result in the modulation of PPI, ultimately altering the TEAD's CYR61, CTGF gene expression. In particular, the 2-(4-hydroxyanilino)-naphthoquinone scaffold of IA5 may establish hydrogen bonds, aromatic contacts, and a favorable interaction between the central electron-poor quinone ring and the electron-rich peptidic carbonyls aromatic residues; all recognized as common key motifs in iPPI [81]. While IA5 has been reported for its capability to affect the cell cycle [66] and for its selective antiproliferative effect on cancer cell lines [82], to the best of our knowledge this is the first time that its activity was evaluated in the context of the Hippo signaling cascade. The detailed mechanism of action of IA5 compound will be explored in future experiments, to guide further medicinal chemistry work, leading to more selective YAP-TEAD activity modulators.

Supplementary Materials: The following are available online at https:/ / www.mdpi.com/article/ 10.3390/pharmaceutics14020391/s1. Supplementary Materials (SM). Figure S1. and description of the Sunburst chart of the Hippo pathway inhibitors. Chemistry Synthesis of ST11cis. NMR spectra of DA15. Table S1. List of the chemical library of 27 compounds tested in HaCat cells. Table S2: Drug-likeness properties of compound library. Table S3: Data summary from the PCA analysis. Table S4. MTT cell growth inhibition ( $48 \mathrm{~h}$ ). Table S5. MTT cell growth inhibition (18 h). Figure S2. In silico analysis for physico and chemical property characterization. Figure S3. Scree-plot and variance explained for each principal component (PC). Figure S4. Growth inhibition assay. Figure S5. MTT assay of HaCaT cells. Supplementary Materials File 1 (SM1). Figure S1a. AGC 35. Hippo pathway network. Figure S1(b). AGC 35. Hippo network MCL clusterization. Figure S2a. ULA26. Hippo interacting network. Figure S2b. ULA26. Hippo network MCL clusterization. Figure S3a. PCM129 and UPR1355. Hippo interacting network. Figure S3b. PCM129 and UPR1355. Hippo network MCL clusterization. Figure S4a. CDM38 and BAT33. Hippo interacting network. Figure S4b. CDM38 and BAT33. Hippo network MCL clusterization analysis. Figure S5. Memoquin and RS34. Hippo network MCL clusterization analysis. Figure S6a. JCM24 and SVT118. Hippo interacting STRING network. Figure S6b. JCM24 and SVT118. Hippo network MCL clusterization analysis. Figure S7. URB913. Hippo interacting network. Figure S8. Digoxin and digoxygenin. Hippo interacting network. Figure S9. Pristimerim. Hippo STRING interacting network. Figure S10. UCM871/UCM765. Hippo STRING interacting network. Figure S11. ANTIPAO. Hippo STRING interacting network. Figure S12. URP1320. Hippo STRING interacting network. Figure S13. URP1268. Hippo STRING interacting network. Figure S14. URB694. Hippo STRING interacting network.

Author Contributions: Conceptualization, M.P.C., D.D. and M.L.B., M.M., S.F.; methodology, D.D., M.S., A.L.; formal analysis, M.S., E.U.; investigation, L.T., A.L., G.G., G.M., M.L.B., M.M., L.S., E.U.; resources, M.P.C., M.L.B., M.M., D.D., G.M.; data curation, S.F., G.M.E., A.L., M.S.; writing—original draft preparation, A.L., M.P.C., M.L.B., M.M., G.M., L.S.; writing-review and editing, A.L., E.U, M.P.C., M.L.B.,M.S., M.M., L.L., L.S.; visualization and design, A.L., M.P.C., M.L.B., M.M., E.U.; funding acquisition, M.P.C., M.L.B., M.M.; All authors have read and agreed to the published version of the manuscript.

Funding: The present work was partly supported by the EU-Emilia Romagna Spinner 2013, regional Ph.D. project NOVAMOLSTAM. "New molecules for the control and differentiation of stem cells" 2013-2015; FAR 2021 Mission Oriented-FAR2021INTERM_O_UNIM.

Institutional Review Board Statement: Not applicable.

Data Availability Statement: Data supporting the reported results can be found at the following address: https: / / zenodo.org/deposit/4624361, accessed on 20 November 2021. Raw data file associated to cellular studies of the manuscript are reported in the file "raw data_YapExp_cellular experiments.xlsx" and deposited in the following website https://zenodo.org/deposit/4624361, accessed on 20 November 2021. Raw data file associated with Figure 7 of the manuscript is reported in the following file "RAW IMAGEWB_Figure7.pdf" and deposited in the following website https:/ / zenodo.org/deposit/4624361, accessed on 20 November 2021.

Acknowledgments: Marinella Roberti (University of Bologna) and Josè Carlos Menendez (Complutense University of Madrid) are gratefully acknowledged for providing compound ST11 (cis/trans) 
and JCM24, respectively, and for insightful discussion. We thank Glauco Ponterini for the critical reading of the manuscript.

Conflicts of Interest: The authors declare no conflict of interest.

\section{References}

1. Maugeri-Saccà, M.; Barba, M.; Pizzuti, L.; Vici, P.; Di Lauro, L.; Dattilo, R.; Vitale, I.; Bartucci, M.; Mottolese, M.; De Maria, R. The Hippo transducers TAZ and YAP in breast cancer: Oncogenic activities and clinical implications. Expert Rev. Mol. Med. 2015, 17, e14. [CrossRef] [PubMed]

2. Bartucci, M.; Dattilo, R.; Moriconi, C.; Pagliuca, A.; Mottolese, M.; Federici, G.; Di Benedetto, A.; Todaro, M.; Stassi, G.; Sperati, F.; et al. TAZ is required for metastatic activity and chemoresistance of breast cancer stem cells. Oncogene 2014, 34, 681-690. [CrossRef] [PubMed]

3. Wang, L.; Shi, S.; Guo, Z.; Zhang, X.; Han, S.; Yang, A.; Wen, W.; Zhu, Q. Overexpression of YAP and TAZ is an independent predictor of prognosis in colorectal cancer and related to the proliferation and metastasis of colon cancer cells. PLoS ONE 2013, 8, e65539. [CrossRef] [PubMed]

4. An Integrative Analysis of the Tumorigenic Role of TAZ in Human Non-Small Cell Lung Cancer I Clinical Cancer Research, (n.d.). Available online: https:/ / clincancerres.aacrjournals.org/content/20/17/4660.long (accessed on 1 April 2020).

5. Santucci, M.; Vignudelli, T.; Ferrari, S.; Mor, M.; Scalvini, L.; Bolognesi, M.L.; Uliassi, E.; Costi, M.P. The Hippo Pathway and YAP/TAZ-TEAD Protein-Protein Interaction as Targets for Regenerative Medicine and Cancer Treatment. J. Med. Chem. 2015, 58, 4857-4873. [CrossRef]

6. Lamar, J.M.; Xiao, Y.; Norton, E.; Jiang, Z.-G.; Gerhard, G.M.; Kooner, S.; Warren, J.S.A.; Hynes, R.O. SRC tyrosine kinase activates the YAP/TAZ axis and thereby drives tumor growth and metastasis. J. Biol. Chem. 2019, 294, 2302-2317. [CrossRef]

7. Tremblay, A.M.; Camargo, F.D. Hippo signaling in mammalian stem cells. Semin. Cell Dev. Biol. 2012, 23, 818-826. [CrossRef]

8. Yu, F.-X.; Guan, K.-L. The Hippo pathway: Regulators and regulations. Genes Dev. 2013, 27, 355-371. [CrossRef]

9. Sayedyahossein, S.; Li, Z.; Hedman, A.C.; Morgan, C.; Sacks, D.B. IQGAP1 Binds to Yes-associated Protein (YAP) and Modulates Its Transcriptional Activity. J. Biol. Chem. 2016, 291, 19261-19273. [CrossRef]

10. Taha, Z.; Van Rensburg, H.J.J.; Yang, X. The Hippo Pathway: Immunity and Cancer. Cancers 2018, 10, 94. [CrossRef]

11. Holden, J.; Cunningham, C. Targeting the Hippo Pathway and Cancer through the TEAD Family of Transcription Factors. Cancers 2018, 10, 81. [CrossRef]

12. Liu-Chittenden, Y.; Huang, B.; Shim, J.S.; Chen, Q.; Lee, S.-J.; Anders, R.A.; Liu, J.O.; Pan, D. Genetic and pharmacological disruption of the TEAD-YAP complex suppresses the oncogenic activity of YAP. Genes Dev. 2012, 26, 1300-1305. [CrossRef]

13. Elisi, G.M.; Santucci, M.; D’Arca, D.; Lauriola, A.; Marverti, G.; Losi, L.; Scalvini, L.; Bolognesi, M.L.; Mor, M.; Costi, M.P. Repurposing of Drugs Targeting YAP-TEAD Functions. Cancers 2018, 10, 329. [CrossRef]

14. Pobbati, A.V.; Hong, W. A combat with the YAP/TAZ-TEAD oncoproteins for cancer therapy. Theranostics 2020, 10, 3622-3635. [CrossRef]

15. Stanger, B.Z. Quit your YAPing: A new target for cancer therapy. Genes Dev. 2012, 26, 1263-1267. [CrossRef]

16. Dong, L.; Lin, F.; Wu, W.; Liu, Y.; Huang, W. Verteporfin inhibits YAP-induced bladder cancer cell growth and invasion via Hippo signaling pathway. Int. J. Med. Sci. 2018, 15, 645-652. [CrossRef]

17. Eales, K.L.; Wilkinson, E.; Cruickshank, G.; Tucker, J.; Tennant, D.A. Verteporfin selectively kills hypoxic glioma cells through iron-binding and increased production of reactive oxygen species. Sci. Rep. 2018, 8, 1-12. [CrossRef]

18. Nouri, K.; Azad, T.; Ling, M.; Van Rensburg, H.J.J.; Pipchuk, A.; Shen, H.; Hao, Y.; Zhang, J.; Yang, X. Identification of Celastrol as a Novel YAP-TEAD Inhibitor for Cancer Therapy by High Throughput Screening with Ultrasensitive YAP/TAZ-TEAD Biosensors. Cancers 2019, 11, 1596. [CrossRef]

19. Zhang, Z.; Lin, Z.; Zhou, Z.; Shen, H.C.; Yan, S.F.; Mayweg, A.V.; Xu, Z.; Qin, N.; Wong, J.C.; Zhang, Z.; et al. Structure-Based Design and Synthesis of Potent Cyclic Peptides Inhibiting the YAP-TEAD Protein-Protein Interaction. ACS Med. Chem. Lett. 2014, 5, 993-998. [CrossRef]

20. Crook, Z.R.; Sevilla, G.P.; Friend, D.; Brusniak, M.-Y.; Bandaranayake, A.D.; Clarke, M.; Gewe, M.; Mhyre, A.J.; Baker, D.; Strong, R.K.; et al. Mammalian display screening of diverse cystine-dense peptides for difficult to drug targets. Nat. Commun. 2017, 8, 2244. [CrossRef]

21. Jiao, S.; Wang, H.; Shi, Z.; Dong, A.; Zhang, W.; Song, X.; He, F.; Wang, Y.; Zhang, Z.; Wang, W.; et al. A Peptide Mimicking VGLL4 Function Acts as a YAP Antagonist Therapy against Gastric Cancer. Cancer Cell 2014, 25, 166-180. [CrossRef]

22. Smith, S.A.; Sessions, R.B.; Shoemark, D.K.; Williams, C.; Ebrahimighaei, R.; McNeill, M.C.; Crump, M.P.; McKay, T.R.; Harris, G.; Newby, A.C.; et al. Antiproliferative and Antimigratory Effects of a Novel YAP-TEAD Interaction Inhibitor Identified Using in Silico Molecular Docking. J. Med. Chem. 2019, 62, 1291-1305. [CrossRef] [PubMed]

23. Sudol, M.; Shields, D.C.; Farooq, A. Structures of YAP protein domains reveal promising targets for development of new cancer drugs. Semin. Cell Dev. Biol. 2012, 23, 827-833. [CrossRef] [PubMed]

24. Xu, J.; Li, P.-X.; Wu, J.; Gao, Y.-J.; Yin, M.-X.; Lin, Y.; Yang, M.; Chen, D.-P.; Sun, H.-P.; Liu, Z.-B.; et al. Involvement of the Hippo pathway in regeneration and fibrogenesis after ischaemic acute kidney injury: YAP is the key effector. Clin. Sci. 2016, 130, 349-363. [CrossRef] [PubMed] 
25. Lu, W.; Wang, J.; Li, Y.; Tao, H.; Xiong, H.; Lian, F.; Gao, J.; Ma, H.; Lu, T.; Zhang, D.; et al. Discovery and biological evaluation of vinylsulfonamide derivatives as highly potent, covalent TEAD autopalmitoylation inhibitors. Eur. J. Med. Chem. 2019, 184, 111767. [CrossRef]

26. Kaneda, A.; Seike, T.; Uemori, T.; Myojo, K.; Aida, K.; Danjo, T.; Nakajima, T.; Yamaguchi, D.; Hamada, T.; Tsuji, Y.; et al. Abstract 3086: Discovery of a first-in-class TEAD inhibitor which directly inhibits YAP/TAZ-TEAD protein-protein interaction and shows a potent anti-tumor effect in malignant pleural mesothelioma. In Experimental and Molecular Therapeutics; American Association for Cancer Research: Philadelphia, PA, USA, 2019. [CrossRef]

27. Torchet, R.; Druart, K.; Ruano, L.C.; Moine-Franel, A.; Borges, H.; Doppelt-Azeroual, O.; Brancotte, B.; Mareuil, F.; Nilges, M.; Ménager, H.; et al. The iPPI-DB initiative: A community-centered database of protein-protein interaction modulators. Bioinformatics 2021, 37, 89-96. [CrossRef]

28. Kouassi, K.A.R.; Ganiyou, A.; Benié, A.; Koné, M.G.-R.; Nobel, N.K.; Bohoussou, K.V.; Coulibaly, W.K. Identification of Potential C-kit Protein Kinase Inhibitors Associated with Human Liver Cancer: Atom-based 3D-QSAR Modeling, Pharmacophores-based Virtual Screening and Molecular Docking Studies. Am. J. Pharmacol. Sci. 2021, 9, 1-29. [CrossRef]

29. González-Medina, M.; Prieto-Martínez, F.D.; Naveja, J.J.; Méndez-Lucio, O.; El-Elimat, T.; Pearce, C.J.; Oberlies, N.H.; Figueroa, M.; Medina-Franco, J.L. Chemoinformatic expedition of the chemical space of fungal products. Future Med. Chem. 2016, 8, 1399-1412. [CrossRef]

30. De Souza, A.S.; Ferreira, L.L.G.; De Oliveira, A.S.; Andricopulo, A.D. Quantitative Structure-Activity Relationships for Structurally Diverse Chemotypes Having Anti-Trypanosoma cruzi Activity. Int. J. Mol. Sci. 2019, 20, 2801. [CrossRef]

31. Rogers, D.; Hahn, M. Extended-Connectivity Fingerprints. J. Chem. Inf. Model. 2010, 50, 742-754. [CrossRef]

32. Bajusz, D.; Rácz, A.; Héberger, K. Why is Tanimoto index an appropriate choice for fingerprint-based similarity calculations? J. Cheminform. 2015, 7, 20. [CrossRef]

33. Shao, J.; Tanner, S.W.; Thompson, N.; Cheatham, T.E. Clustering Molecular Dynamics Trajectories: 1. Characterizing the Performance of Different Clustering Algorithms. J. Chem. Theory Comput. 2007, 3, 2312-2334. [CrossRef]

34. Voicu, A.; Duteanu, N.; Voicu, M.; Vlad, D.; Dumitrascu, V. The rcdk and cluster R packages applied to drug candidate selection. J. Cheminform. 2020, 12, 3. [CrossRef]

35. Rácz, A.; Bajusz, D.; Héberger, K. Life beyond the Tanimoto coefficient: Similarity measures for interaction fingerprints. J. Cheminform. 2018, 10, 48. [CrossRef]

36. Letunic, I.; Bork, P. Interactive tree of life (iTOL) v3: An online tool for the display and annotation of phylogenetic and other trees. Nucleic Acids Res. 2016, 44, W242-W245. [CrossRef]

37. Letunic, I.; Bork, P. Interactive Tree Of Life (iTOL) v4: Recent updates and new developments. Nucleic Acids Res. 2019, 47, W256-W259. [CrossRef]

38. Churi, C.R.; Shroff, R.; Wang, Y.; Rashid, A.; Kang, H.; Weatherly, J.; Zuo, M.; Zinner, R.; Hong, D.; Meric-Bernstam, F.; et al. Mutation Profiling in Cholangiocarcinoma: Prognostic and Therapeutic Implications. PLoS ONE 2014, 9, e115383. [CrossRef]

39. Corvaisier, M.; Bauzone, M.; Corfiotti, F.; Renaud, F.; El Amrani, M.; Monté, D.; Truant, S.; Leteurtre, E.; Formstecher, P.; Van Seuningen, I.; et al. Regulation of cellular quiescence by YAP/TAZ and Cyclin E1 in colon cancer cells: Implication in chemoresistance and cancer relapse. Oncotarget 2016, 7, 56699-56712. [CrossRef]

40. Keskin, O.; Gursoy, A.; Ma, B.; Nussinov, R. Principles of Protein-Protein Interactions: What are the Preferred Ways For Proteins To Interact? Chem. Rev. 2008, 108, 1225-1244. [CrossRef]

41. Kuenemann, M.A.; Bourbon, L.M.L.; Labbé, C.M.; Villoutreix, B.; Sperandio, O. Which Three-Dimensional Characteristics Make Efficient Inhibitors of Protein-Protein Interactions? J. Chem. Inf. Model. 2014, 54, 3067-3079. [CrossRef]

42. Benet, L.Z.; Hosey, C.M.; Ursu, O.; Oprea, T. BDDCS, the Rule of 5 and drugability. Adv. Drug Deliv. Rev. 2016, 101, 89-98. [CrossRef]

43. Björklund, M. Be careful with your principal components. Evolution 2019, 73, 2151-2158. [CrossRef] [PubMed]

44. Rodionova, O.; Kucheryavskiy, S.; Pomerantsev, A. Efficient tools for principal component analysis of complex data-A tutorial. Chemom. Intell. Lab. Syst. 2021, 213, 104304. [CrossRef]

45. Cavalli, A.; Bolognesi, M.L.; Capsoni, S.; Andrisano, V.; Bartolini, M.; Margotti, E.; Cattaneo, A.; Recanatini, M.; Melchiorre, C. A Small Molecule Targeting the Multifactorial Nature of Alzheimer's Disease. Angew. Chem. Int. Ed. 2007, 46, 3689-3692. [CrossRef] [PubMed]

46. Bongarzone, S.; Tran, H.N.A.; Cavalli, A.; Roberti, M.; Carloni, P.; Legname, G.; Bolognesi, M.L. Parallel Synthesis, Evaluation, and Preliminary Structure-Activity Relationship of 2,5-Diamino-1,4-benzoquinones as a Novel Class of Bivalent Anti-Prion Compound. J. Med. Chem. 2010, 53, 8197-8201. [CrossRef]

47. Kawahara, G.; Gasperini, M.J.; Myers, J.A.; Widrick, J.J.; Eran, A.; Serafini, P.R.; Alexander, M.S.; Pletcher, M.T.; Morris, C.A.; Kunkel, L.M. Dystrophic muscle improvement in zebrafish via increased heme oxygenase signaling. Hum. Mol. Genet. 2013, 23, 1869-1878. [CrossRef]

48. Uliassi, E.; Fiorani, G.; Krauth-Siegel, R.L.; Bergamini, C.; Fato, R.; Bianchini, G.; Menéndez, J.C.; Molina, M.T.; López-Montero, E.; Falchi, F.; et al. Crassiflorone derivatives that inhibit Trypanosoma brucei glyceraldehyde-3-phosphate dehydrogenase (Tb GAPDH) and Trypanosoma cruzi trypanothione reductase (Tc TR) and display trypanocidal activity. Eur. J. Med. Chem. 2017, 141, 138-148. [CrossRef] 
49. Bolognesi, M.L.; Marucci, G.; Angeli, P.; Buccioni, M.; Minarini, A.; Rosini, M.; Tumiatti, V.; Melchiorre, C. Analogues of Prazosin That Bear a Benextramine-Related Polyamine Backbone Exhibit Different Antagonism toward $\alpha 1$-Adrenoreceptor Subtypes. J. Med. Chem. 2000, 44, 362-371. [CrossRef]

50. Bolognesi, M.L.; Budriesi, R.; Chiarini, A.; Poggesi, E.; Leonardi, A.; Melchiorre, C. Design, Synthesis, and Biological Activity of Prazosin-Related Antagonists. Role of the Piperazine and Furan Units of Prazosin on the Selectivity for $\alpha 1$-Adrenoreceptor Subtypes. J. Med. Chem. 1998, 41, 4844-4853. [CrossRef]

51. Carmi, C.; Galvani, E.; Vacondio, F.; Rivara, S.; Lodola, A.; Russo, S.; Aiello, S.; Bordi, F.; Costantino, G.; Cavazzoni, A.; et al. Irreversible Inhibition of Epidermal Growth Factor Receptor Activity by 3-Aminopropanamides. J. Med. Chem. 2012, 55, $2251-2264$. [CrossRef]

52. Roberti, M.; Pizzirani, D.; Recanatini, M.; Simoni, D.; Grimaudo, S.; Di Cristina, A.; Abbadessa, V.; Gebbia, A.N.; Tolomeo, M. Identification of a Terphenyl Derivative that Blocks the Cell Cycle in the G0-G1 Phase and Induces Differentiation in Leukemia Cells. J. Med. Chem. 2006, 49, 3012-3018. [CrossRef]

53. Gandini, A.; Bartolini, M.; Tedesco, D.; Martinez-Gonzalez, L.; Roca, C.; Campillo, N.E.; Zaldivar-Diez, J.; Perez, C.; Zuccheri, G.; Miti, A.; et al. Tau-Centric Multitarget Approach for Alzheimer's Disease: Development of First-in-Class Dual Glycogen Synthase Kinase $3 \beta$ and Tau-Aggregation Inhibitors. J. Med. Chem. 2018, 61, 7640-7656. [CrossRef]

54. Bolognesi, M.L.; Tran, H.N.A.; Staderini, M.; Monaco, A.; López-Cobeñas, A.; Bongarzone, S.; Biarnés, X.; López-Alvarado, P.; Cabezas, N.; Caramelli, M.; et al. Discovery of a Class of Diketopiperazines as Antiprion Compounds. ChemMedChem 2010, 5, 1324-1334. [CrossRef]

55. Bolognesi, M.L.; Cavalli, A.; Valgimigli, L.; Bartolini, M.; Rosini, M.; Andrisano, V.; Recanatini, M.; Melchiorre, C. Multi-TargetDirected Drug Design Strategy: From a Dual Binding Site Acetylcholinesterase Inhibitor to a Trifunctional Compound against Alzheimer's Disease. J. Med. Chem. 2007, 50, 6446-6449. [CrossRef]

56. Uliassi, E.; Pena-Altamira, E.; Morales, A.V.; Massenzio, F.; Petralla, S.; Rossi, M.; Roberti, M.; Gonzalez, L.M.; Martinez, A.; Monti, B.; et al. A Focused Library of Psychotropic Analogues with Neuroprotective and Neuroregenerative Potential. ACS Chem. Neurosci. 2018, 10, 279-294. [CrossRef]

57. King, A.R.; Dotsey, E.Y.; Lodola, A.; Jung, K.-M.; Ghomian, A.; Qiu, Y.; Fu, J.; Mor, M.; Piomelli, D. Discovery of Potent and Reversible Monoacylglycerol Lipase Inhibitors. Chem. Biol. 2009, 16, 1045-1052. [CrossRef]

58. Tarzia, G.; Duranti, A.; Gatti, G.; Piersanti, G.; Tontini, A.; Rivara, S.; Lodola, A.; Plazzi, P.V.; Mor, M.; Kathuria, S.; et al. Synthesis and Structure-Activity Relationships of FAAH Inhibitors: Cyclohexylcarbamic Acid Biphenyl Esters with Chemical Modulation at the Proximal Phenyl Ring. ChemMedChem 2006, 1, 130-139. [CrossRef]

59. Duranti, A.; Tontini, A.; Antonietti, F.; Vacondio, F.; Fioni, A.; Silva, C.; Lodola, A.; Rivara, S.; Solorzano, C.; Piomelli, D.; et al. N-(2-Oxo-3-oxetanyl)carbamic Acid Esters as N-Acylethanolamine Acid Amidase Inhibitors: Synthesis and Structure-Activity and Structure-Property Relationships. J. Med. Chem. 2012, 55, 4824-4836. [CrossRef]

60. Drakes, M.L.; Stiff, P.J. Regulation of Ovarian Cancer Prognosis by Immune Cells in the Tumor Microenvironment. Cancers 2018, 10, 302. [CrossRef]

61. Hassan-Mohamed, I.; Giorgio, C.; Incerti, M.; Russo, S.; Pala, D.; Pasquale, E.B.; Zanotti, I.; Vicini, P.; Barocelli, E.; Rivara, S.; et al. UniPR129 is a competitive small molecule Eph-ephrin antagonist blocking in vitro angiogenesis at low micromolar concentrations: Eph antagonist and angiogenesis. Br. J. Pharmacol. 2014, 171, 5195-5208. [CrossRef]

62. Schwartz, A.; Allen, J.C.; Harigaya, S. Possible involvement of cardiac Na+, K+-adenosine triphosphatase in the mechanism of action of cardiac glycosides. J. Pharmacol. Exp. Ther. 1969, 168, 31-41.

63. Rivara, S.; Lodola, A.; Mor, M.; Bedini, A.; Spadoni, G.; Lucini, V.; Pannacci, M.; Fraschini, F.; Scaglione, F.; Sanchez, R.O.; et al. N-(Substituted-anilinoethyl)amides: Design, Synthesis, and Pharmacological Characterization of a New Class of Melatonin Receptor Ligands. J. Med. Chem. 2007, 50, 6618-6626. [CrossRef]

64. Rivara, S.; Pala, D.; Lodola, A.; Mor, M.; Lucini, V.; Dugnani, S.; Scaglione, F.; Bedini, A.; Lucarini, S.; Tarzia, G.; et al. $\mathrm{MT}_{1}$-Selective Melatonin Receptor Ligands: Synthesis, Pharmacological Evaluation, and Molecular Dynamics Investigation of $\mathrm{N}-\{[(3-\mathrm{O}-S u b s t i t u t e d) a n i l i n o] a l k y l\} a m i d e s$. ChemMedChem 2012, 7, 1954-1964. [CrossRef]

65. Song, S.; Honjo, S.; Jin, J.; Chang, S.-S.; Scott, A.W.; Chen, Q.; Kalhor, N.; Correa, A.M.; Hofstetter, W.L.; Albarracin, C.T.; et al. The Hippo Coactivator YAP1 Mediates EGFR Overexpression and Confers Chemoresistance in Esophageal Cancer. Clin. Cancer Res. 2015, 21, 2580-2590. [CrossRef]

66. Murphey, R.D.; Stern, H.M.; Straub, C.T.; Zon, L.I. A Chemical Genetic Screen for Cell Cycle Inhibitors in Zebrafish Embryos. Chem. Biol. Drug Des. 2006, 68, 213-219. [CrossRef]

67. Yousef, B.; Hassan, H.M.; Guerram, M.; Hamdi, A.M.; Wang, B.; Zhang, L.-Y.; Jiang, Z.-Z. Pristimerin inhibits proliferation, migration and invasion, and induces apoptosis in HCT-116 colorectal cancer cells. Biomed. Pharmacother. 2016, 79, 112-119. [CrossRef]

68. Galvani, E.; Giovannetti, E.; Saccani, F.; Cavazzoni, A.; Leon, L.G.; Dekker, H.; Alfieri, R.; Carmi, C.; Mor, M.; Ardizzoni, A.; et al. Molecular Mechanisms Underlying the Antitumor Activity of 3-Aminopropanamide Irreversible Inhibitors of the Epidermal Growth Factor Receptor in Non-Small Cell Lung Cancer. Neoplasia 2013, 15, 61-72, IN18. [CrossRef]

69. Huang, H.; Zhang, W.; Pan, Y.; Gao, Y.; Deng, L.; Li, F.; Li, F.; Ma, X.; Hou, S.; Xueyan, M.; et al. YAP Suppresses Lung Squamous Cell Carcinoma Progression via Deregulation of the DNp63-GPX2 Axis and ROS Accumulation. Cancer Res. 2017, 77, 5769-5781. [CrossRef] 
70. Solberg, N.; Krauss, S. Luciferase Assay to Study the Activity of a Cloned Promoter DNA Fragment. In Gene Regulation; Humana Press: Totowa, NJ, USA, 2013; Volume 977, pp. 65-78. [CrossRef]

71. Li, Z.; Feng, J.; Gou, J.; Jia, J.; Yi, T.; Cui, T. Verteporfin, a suppressor of YAP-TEAD complex, presents promising antitumor properties on ovarian cancer. OncoTargets Ther. 2016, 9, 5371-5381. [CrossRef]

72. Ma, Y.-W.; Liu, Y.-Z.; Pan, J.-X. Verteporfin induces apoptosis and eliminates cancer stem-like cells in uveal melanoma in the absence of light activation. Am. J. Cancer Res. 2016, 6, 2816-2830.

73. Su, M.; Zhan, L.; Zhang, Y.; Zhang, J. Yes-activated protein promotes primary resistance of BRAF V600E mutant metastatic colorectal cancer cells to mitogen-activated protein kinase pathway inhibitors. J. Gastrointest. Oncol. 2021, 12, 953-963. [CrossRef]

74. Ling, H.-H.; Kuo, C.-C.; Lin, B.-X.; Huang, Y.-H.; Lin, C.-W. Elevation of YAP promotes the epithelial-mesenchymal transition and tumor aggressiveness in colorectal cancer. Exp. Cell Res. 2017, 350, 218-225. [CrossRef] [PubMed]

75. Plouffe, S.W.; Lin, K.C.; Moore, J.L.; Tan, F.E.; Ma, S.; Ye, Z.; Qiu, Y.; Ren, B.; Guan, K.-L. The Hippo pathway effector proteins YAP and TAZ have both distinct and overlapping functions in the cell. J. Biol. Chem. 2018, 293, 11230-11240. [CrossRef] [PubMed]

76. Wang, C.; Zhu, X.; Feng, W.; Yu, Y.; Jeong, K.; Guo, W.; Lu, Y.; Mills, G.B. Verteporfin inhibits YAP function through up-regulating 14-3-3 $\sigma$ sequestering YAP in the cytoplasm. Am. J. Cancer Res. 2015, 6, 27-37. [PubMed]

77. Lei, Q.-Y.; Zhang, H.; Zhao, B.; Zha, Z.; Bai, F.; Pei, X.-H.; Zhao, S.; Xiong, Y.; Guan, K.-L. TAZ Promotes Cell Proliferation and Epithelial-Mesenchymal Transition and Is Inhibited by the Hippo Pathway. Mol. Cell. Biol. 2008, 28, 2426-2436. [CrossRef]

78. Bolton, J.L.; Dunlap, T. Formation and Biological Targets of Quinones: Cytotoxic versus Cytoprotective Effects. Chem. Res. Toxicol. 2016, 30, 13-37. [CrossRef]

79. Wang, W.; Lin, P.; Zhang, Z.; Zhong, Y.; Kong, D. Digoxin Enhances the Anticancer Effect on Non-Small Cell Lung Cancer While Reducing the Cardiotoxicity of Adriamycin. Front. Pharmacol. 2020, 11, 186. [CrossRef]

80. Shao, D.; Zhai, P.; Del Re, D.P.; Sciarretta, S.; Yabuta, N.; Nojima, H.; Lim, D.-S.; Pan, D.; Sadoshima, J. A functional interaction between Hippo-YAP signalling and FoxO1 mediates the oxidative stress response. Nat. Commun. 2014, 5, 3315. [CrossRef]

81. Sperandio, O.; Reynès, C.H.; Camproux, A.-C.; Villoutreix, B. Rationalizing the chemical space of protein-protein interaction inhibitors. Drug Discov. Today 2010, 15, 220-229. [CrossRef]

82. Sieveking, I.; Thomas, P.; Estévez, J.C.; Quiñones, N.; Cuéllar, M.A.; Villena, J.; Espinosa-Bustos, C.; Fierro, A.; Tapia, R.A.; Maya, J.D.; et al. 2-Phenylaminonaphthoquinones and related compounds: Synthesis, trypanocidal and cytotoxic activities. Bioorg. Med. Chem. 2014, 22, 4609-4620. [CrossRef] 